\title{
Tectono-stratigraphic evolution of the Southern Campania Margin: a key area for the evolution of the Tyrrhenian-Apennine system
}

\author{
Pietro Iannace $^{1}$, Maurizio M. Torrente ${ }^{1, *}$, and Alfonsa Milia ${ }^{2}$ \\ ${ }^{1}$ DST, Università del Sannio, Via Portarsa 11, 82100 Benevento, Italy \\ ${ }^{2}$ IAMC, CNR, Calata Porta di Massa, Porto di Napoli, 80100 Naples, Italy
}

Received: 11 April 2018 / Accepted: 12 July 2018

\begin{abstract}
The Southern Campania Margin (SCM) represents a key area of the Central Mediterranean because it records all the rifting stages of the Tyrrhenian Sea. The interpretation of a seismic dataset calibrated with deep wells and outcrops, using seismic stratigraphy and structural geology methods in a dedicated Geographic Information System (GIS) environment, the seismic depth conversion, the generation of 2-D and 3-D models led to the reconstruction of a polyphased tectono-stratigraphic evolution of the SCM. During the early stage of Tyrrhenian opening a terrigenous transtensional basin (Langhian-Tortonian Cilento Basin) formed on the Liguride accretionary prism adjacent to the Calabria crystalline terrane. In the SCM the Liguride thrust sheets tectonically overly the Apennine Platform units and both these nappes have been dismembered by Quaternary faults. Three rifting stages, not homogeneously distributed, affected the region since the Lower Pleistocene. They are associated to the deposition of a thick Quaternary succession (A, B and C units). During these Pleistocene stages there was an abrupt change of the extension direction (from NE-SW to NW-SE) accompanying a change of the nappe transport direction of the Southern Apennines. The construction of balanced sections using dedicated software, permitted us to recognize the true geometry of the faults and compute the amount of Quaternary extension of the SCM that results comparable to those calculated for other sectors of the Tyrrhenian margin and further extensional regions worldwide.
\end{abstract}

\section{Introduction}

The Southern Campania Margin (hereinafter SCM); is located in the hinge area between the Southern Apennines fold-and-thrust belt and the Southern Tyrrhenian backarc basin and it borders the Calabria terrane made up of pre-Mesozoic basement internal units (Fig. 1).

The Southern Apennines thrust belt trends NW-SE (Fig. 2) and consists of a NE-verging accretionary wedge derived from the Neogene shortening of the Africa-Apulian passive margin. In particular, it is formed by three main stacked tectonic elements: i) Jurassic-Cretaceous to early Miocene successions of the internal oceanic to transitional deep-sea domains (Liguride accretionary wedge; Bonardi et al., 1988); ii) Triassic to Miocene carbonate platform and slope successions (Apennine carbonate Platform, after Mostardini and Merlini, 1986); iii) Triassic to Miocene Lagonegro Basin successions (Scandone, 1967; Miconnet, 1988). The Southern Apennines is characterized by thrust sheets transported for several tens of $\mathrm{km}$ over

\footnotetext{
* Corresponding author: torrente@unisannio.it
}

Apulian platform carbonates stratigraphically overlain by Messinian-Pliocene marine sediments, which form the seal of unlocked hydrocarbon traps (Roure et al., 2012).

The opening of the Tyrrhenian Sea started during the Miocene and led to the formation of several rift basins in the Central Mediterranean (e.g. Sartori, 1990, 2003; Milia et al., 2017d). This extensional process continued during the Pliocene in the Vavilov Basin characterized by mantle exhumation and approximately E-W directed extension (Milia et al., 2017c). A fundamental point for the kinematic reconstruction of the Tyrrhenian opening is the behavior of the Calabria terrane that is assumed to migrate toward SE since the Late Messinian (Vitale and Ciarcia, 2013). However, this Calabria terrane's behavior would conflict with an eastwards opening of the Tyrrhenian Sea. Furthermore, the differential motion between the Calabrian terrane and the Southern Apennines is generally associated to sinistral kinematics along the NW-trending Pollino and other fault systems located in Southern Apennines and the Campania Margin (e.g. Patacca et al., 1990; Knott and Turco, 1991; Monaco et al., 1998; Schiattarella et al., 2005). Thus the position of the SCM makes it the ideal place for both studying the tectono-stratigraphic evolution of the Tyrrhenian 


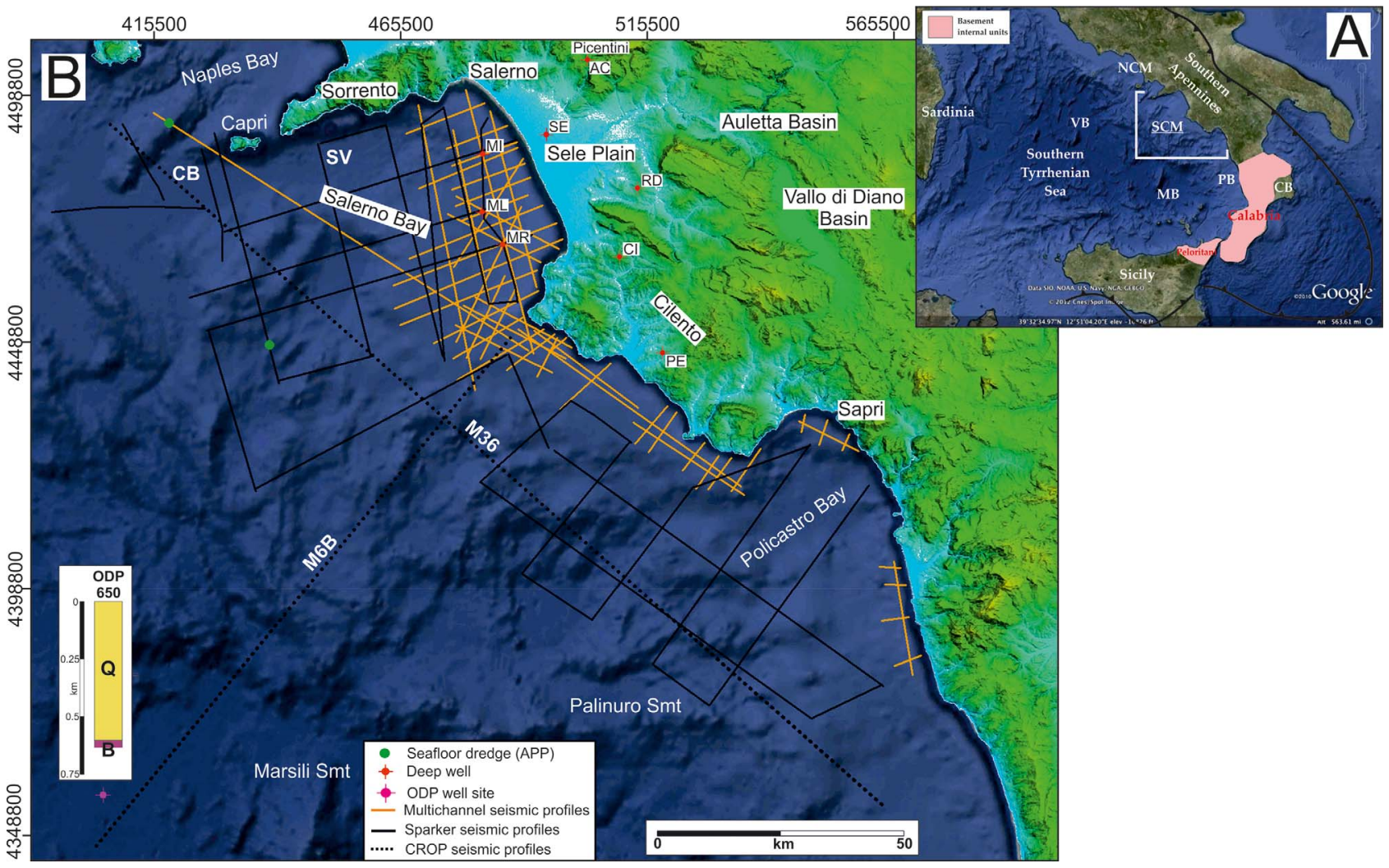

Fig. 1. (a) Index map of Italy and the Tyrrhenian Sea and location of the study area. SCM = Southern Campania Margin, $\mathrm{NCM}=$ Northern Campania Margin, $\mathrm{CB}=$ Crotone Basin, $\mathrm{PB}=$ Paola Basin, $\mathrm{MB}=$ Marsili Basin, VB = Vavilov Basin. (b) Index map of seismic grid, deep wells, seafloor dredges and stratigraphic succession of ODP 650 well site. MI = Mina 1 well, ML $=$ Milena 1 well, $\mathrm{MR}=$ Margherita Mare 1 well, $\mathrm{SE}=$ Sele 1 well, $\mathrm{AC}=$ Acerno 1 well, $\mathrm{RD}=$ Roccadaspide 1 well, CI = Cicerale 1 dir well, $\mathrm{PE}=$ Perdifumo 1 well. $\mathrm{SV}=$ Salerno Valley, $\mathrm{CB}=$ Capri Basin. APP $=$ Apennine platform unit (Mesozoic-Cenozoic). $\mathrm{Q}=$ Quaternary rocks, $\mathrm{B}=$ basalts.

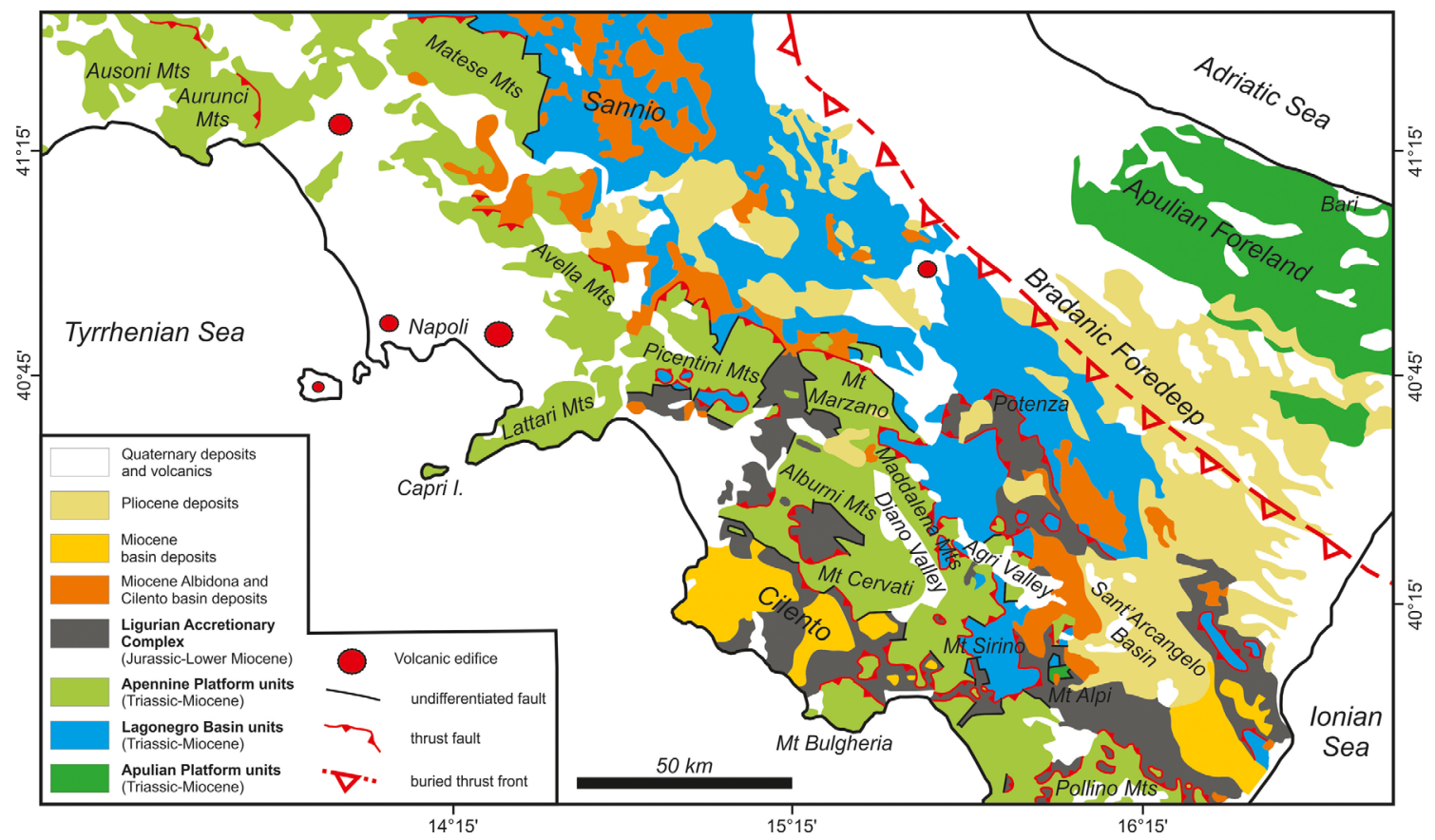

Fig. 2. Tectonic sketch map of the Southern Apennines (modified from Vitale and Ciarcia, 2013). 
margin and constraining the timing of migration of the Calabria terrane.

In recent years, some progress has been made regarding the kinematics of the Tyrrhenian Sea. Continental rifting was initially (Late Serravallian-Upper Tortonian) driven by an early E-SE extensional-transtensional tectonics in the Central Mediterranean (Milia and Torrente, 2014). This event affected the Calabria terrane that was close to the Cilento extensional Basin, presently located on the SCM (Milia et al., 2017d and reference therein). Indeed, the petrographic study of the arenites of the Southern Apennines (Critelli and Le Pera, 1994) documents that the source area of the Cilento Group deposits was the Calabria terrane. During the Pliocene a continental breakup led to the separation of the Sardinia from the Campania margins and the opening of the Vavilov Basin; mantle exhumation took place in the central Tyrrhenian Sea contemporaneously to the construction of the Apennine thrust belt (Milia et al., 2017c; Patacca et al., 1990; Vitale and Ciarcia, 2013). During the Pleistocene the extension propagated toward the East. In the Middle-Upper Pleistocene, extension was localized on the Campania margin and propagate toward SE/ESE (Torrente and Milia, 2013; Milia and Torrente, 2015a; Milia et al., 2017a; 2017b). The MiddleUpper Pleistocene crustal extension dismembered the Campania Margin and resulted in several rift basins like the Campania Plain, Gaeta Bay, Naples Bay and SCM basins (Fig. 1).

Apart from the recent paper of Milia et al. (2017a, $2017 b$ ), previous geological works analyzed only limited part of the SCM. NE-trending normal faults that controlled a thick depocenter $(>2 \mathrm{~km}$, Mina 1 well) have been reported (Sacchi et al., 1994; Casciello et al., 2004) in the Salerno bay. Thus a comprehensive knowledge of SCM as the age of the basin fill, quantitative extension estimates, timing and kinematics of faults, and the link with the Calabria terrane migration are still missing.

The purpose of this paper is manifold: to characterize the structural style and tectono-stratigraphic evolution of the SCM sedimentary basins; to reconstruct the threedimensional architecture of these basins; to produce a depth conversion and balanced cross sections, in order to quantitatively assess the extensional strain that affected the SCM during Quaternary; to document the kinematic evolution of the margin since Miocene.

\section{Materials and methods}

This paper was carried out with an interdisciplinary methodological approach: an integrated data analysis in a dedicated GIS environment (Kingdom, IHS Inc.). We interpreted seismic reflection profiles and wells, made a seismic depth conversion and generated 2-D and 3-D models of relevant geological surfaces (stratigraphic horizons and faults). Indeed, computer technology now makes it possible for geological interpretations to be developed from the beginning in a fully three-dimensional environment (e.g. De Donatis, 2001; Dhont et al., 2005; Smith, 2005; Bigi et al., 2013). Fully 3-D geological models allow significantly better interpretations that are much easier to share with other geologists and with the general public.

The Southern Campania Margin was investigated using a seismic grid formed by three seismic datasets (multichannel seismic profiles, CROP seismic profiles and Sparker data) with different resolution and penetration for a total extension of about $2500 \mathrm{~km}$ (Fig. 1). The first set corresponds to multichannel commercial profiles for hydrocarbon exploration (ViDEPI, 2009), whereas the second set consists of high-penetration profiles acquired during the exploration phase of the Deep Crust (CROP) project (http:// www.crop.cnr.it) (Fig. 1b). Finally, the third seismic dataset was acquired with a Multispot Extended Array System (MEAS). The output power of the MEAS, transmitted through a 36-tip array, was $16 \mathrm{~kJ}$. Vertical recording scales were $2.0 \mathrm{~s}$ with a maximum vertical resolution of $6 \mathrm{~m}$. These data feature a low penetration ( $2 \mathrm{~s}$ of two way-travel-time) and a high resolution.

Raster images of the overall seismic profiles were converted to segy format using image2segy, a free tool developed by Farran (Instituto de Cièncias del Mar, Barcelona University) for MATLAB software, and then collected in a dedicated Geographic Information System (GIS) environment. Line drawing, interpretation of profiles and modeling of geological surfaces were performed using Kingdom software (IHS Inc.); gridding and contouring were performed on geological horizons to generate 2D models (contour maps) and isochron/isopach maps of the sedimentary succession. Iterative testing was carried out in order to select the best algorithm and processing parameters. Finally, 3-D digital models were produced.

The seismic interpretation was made using seismic stratigraphy method: seismic units are groups of seismic reflections, the parameters of which (configuration, amplitude, continuity and frequency) differ from those of adjacent groups. Sedimentary units were delineated on the basis of contact relations and internal and external configurations (e.g. Mitchum et al., 1977). The seismic units were calibrated using the lithostratigraphic and chronostratigraphic data of offshore and onshore boreholes (ViDEPI, 2009) and ODP site 650 (Channell et al., 1990). We performed a review of the stratigraphic units of the Southern Apennines and Campania margin present on the stratigraphic logs using both an updated Planktonic Foraminifera biostratigraphic scheme for the Mediterranean Pliocene and Pleistocene (Patacca and Scandone, 2001). Faults were interpreted on seismic reflection profiles, mapped in a GIS environment, and displayed as lines on structure contour maps and isochron/isopach maps. Due to a relatively strict spacing between 2-D seismic lines $(3-15 \mathrm{~km})$, it was possible to recognize and link major faults based on their geometry, dip direction and amount of throw.

The seismic depth conversion was achieved through the "Dynamic Depth Conversion" tool of the 2d/3dPAKEarthPAK module of the Kingdom software (IHS Inc.). The values of $\mathrm{P}$-waves velocities $\left(V_{\mathrm{p}}\right)$ used in the conversion were obtained from sonic $\log$ of the Milena 1 well and stacking velocities. The raster image of the Milena 1 well sonic $\log$ was imported, calibrated and then digitalized to obtain, through the use of specific algorithms, the 


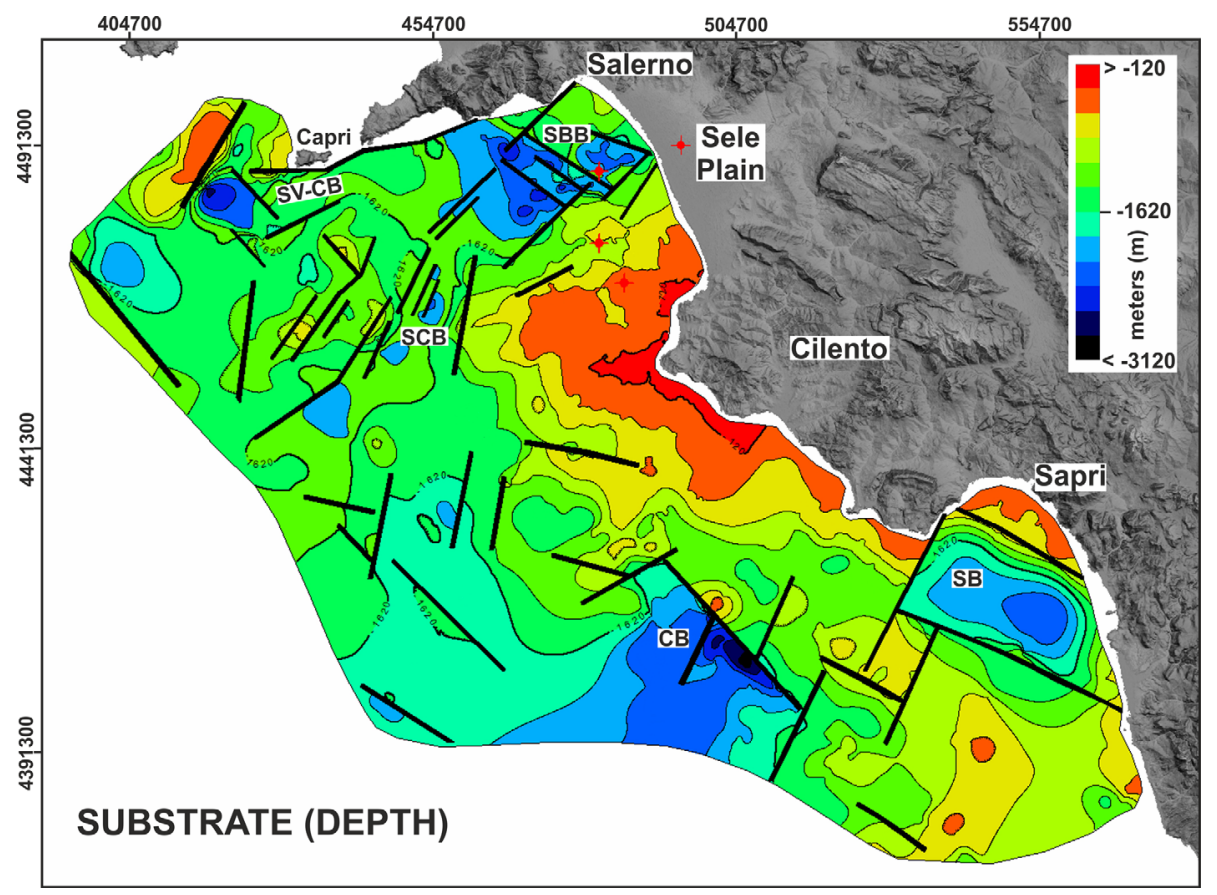

Fig. 3. Depth structure contour map of the acoustic substrate. Abbreviations stand as follows: SBB = Salerno Bay Basin, SV$\mathrm{CB}=$ Salerno Valley-Capri Basin, $\mathrm{SCB}=$ Salerno-Cilento Basin, $\mathrm{CB}=$ Cilento Basin, $\mathrm{SB}=$ Sapri Basin. Bold black lines are faults. Contour interval is $300 \mathrm{~m}$. Map coordinate system: UTM, WGS84.

velocity $\log (\mathrm{m} / \mathrm{s})$. While, the analysis of the stacking velocities, conducted on several seismic profiles, allowed the calculation of the interval velocities (Dix, 1955) and the mean interval velocities over more stacking velocities analysis points in order to reduce the error bounds that affect this type of data.

We found the arithmetic average of the $\mathrm{P}$-waves velocities values for the main lithostratigraphic units drilled by the Milena 1 well. Then, to extend the validity of these values to a larger area, we compared them with interval velocities derived from stacking velocities of several seismic profiles that offer a spatially dense, regular, and objective sampling, and cover the entire depth range evenly throughout the survey area.

The construction of balanced sections and the balancing and restoration of key horizons were performed using the Structure Solver software (copyright 2009-2016 Nunns and Rogan $L L C$ ) which creates paleovertical trajectories in the present day section that correspond to unbroken vertical traces in the restored section (Nunns, 1991). A hybrid approach is used with the following key characteristics: i) length is conserved along the reference horizon; ii) the internal parts of fault blocks are restored using vertical shear; iii) a constant amount of slip is removed along each fault, equal to the slip of the reference horizon across that fault.

\section{Stratigraphy and 3D architecture}

The study of shelf-slope area of the Southern Campania Margin revealed the occurrence of five marine sedimentary basins: Salerno Bay Basin (hereinafter SBB), Salerno Valley-Capri Basin (hereinafter SV-CB), Salerno-Cilento Basin (hereinafter SCB), Cilento Basin (hereinafter $\mathrm{CB}$ ) and Sapri Basin (hereinafter SB) (Fig. 3). The stratigraphic infill of the SCM is thicker than $2400 \mathrm{~m}$ (Fig. 4) and the seismo-stratigraphic interpretation permitted us to recognize three stratigraphic units (A, B, C; see below) unconformably overlying the acoustic substrate $(\mathrm{Mz}, \mathrm{Lc}$ and $\mathrm{Cg}$ units; see below). The boundaries of these units are marked by reflectors that represent major unconformities. Wells drilled offshore and onshore permit to attribute the lithology to every described seismic unit. On the contrary the stratigraphic infill of the Marsili Basin (ODP Site 650; Fig. 1b) corresponds to a $602 \mathrm{~m}$-thick Pleistocene succession dated at the base 2.0 Ma (biozone MPL6/NN18; Channell et al., 1990).

\subsection{Substrate}

The acoustic substrate of the offshore sedimentary basins of the SCM corresponds to three seismic units (Mz, Lc and Cg; Figs. 5 and 6 ) calibrated by wells (Fig. 4).

The lowermost Mz unit is characterized by a reflectionfree seismic facies and is bounded at the top by strong reflectors (Fig. 5), due to the different reflection coefficient between $\mathrm{Mz}$ and Lc units. The Mz unit corresponds to the Mesozoic carbonate of the Apennine Platform, drilled in the deep Mina, Milena and Margherita Mare boreholes (Fig. 4) and outcropping in onshore area.

The Lc unit, overlying the $\mathrm{Mz}$ unit, displays a chaotic seismic facies (Fig. 5) and an erosional surface at the top (unconformity Ux; Fig. 6) offshore the Cilento Promontory. 


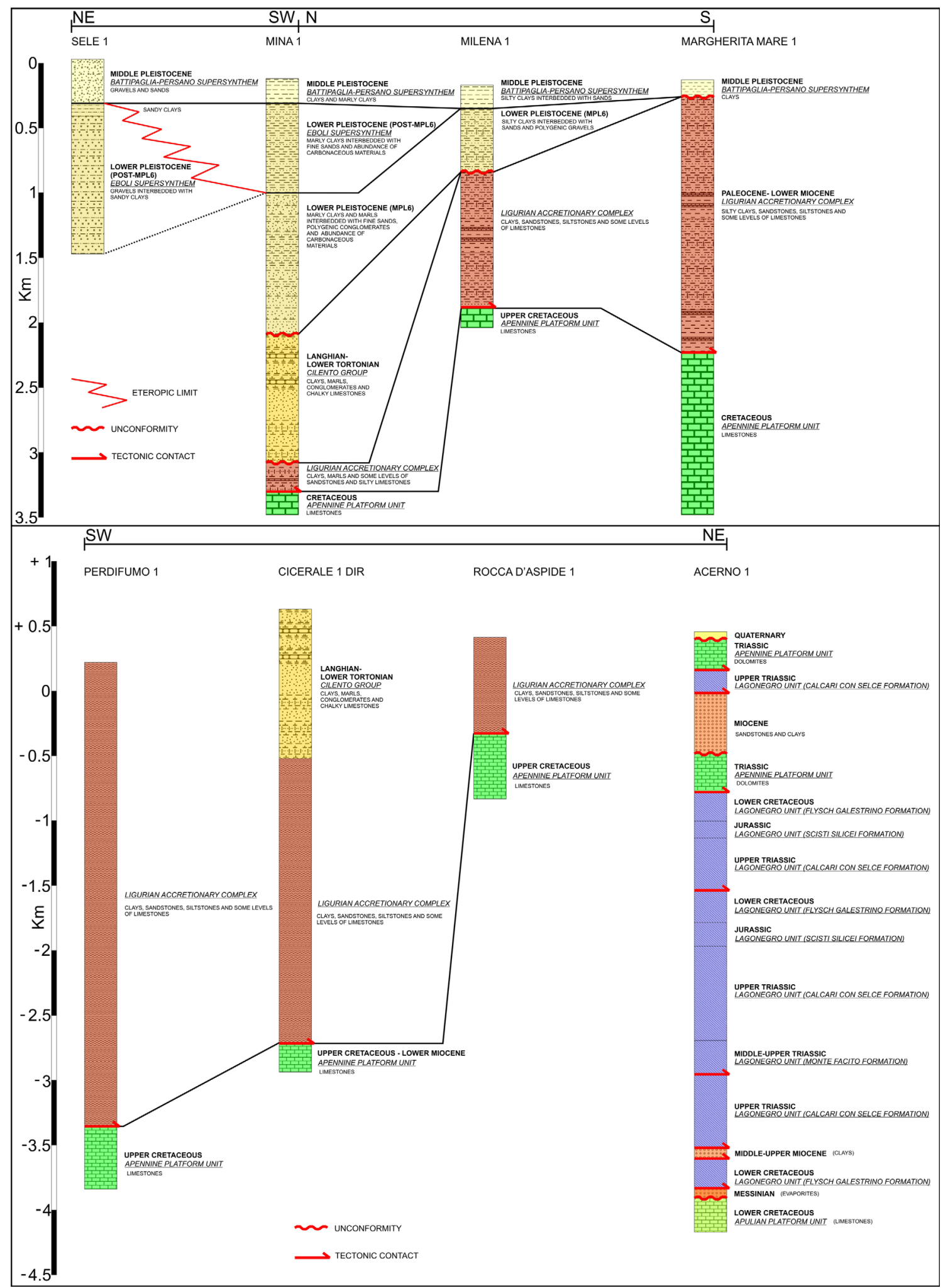

Fig. 4. Stratigraphic successions of deep wells of the Southern Campania Margin (for wells location see Fig. 1b).

It corresponds to highly deformed clays, marls, sandstones with some levels of limestones Paleocene-Lower Miocene in age, whose thickness increases from northwest
(198 m-thick in the Mina 1 well) to southeast (1048 m-thick in the Milena 1 well and 1975 m-thick in the Margherita Mare 1 well). These deposits are equivalent 

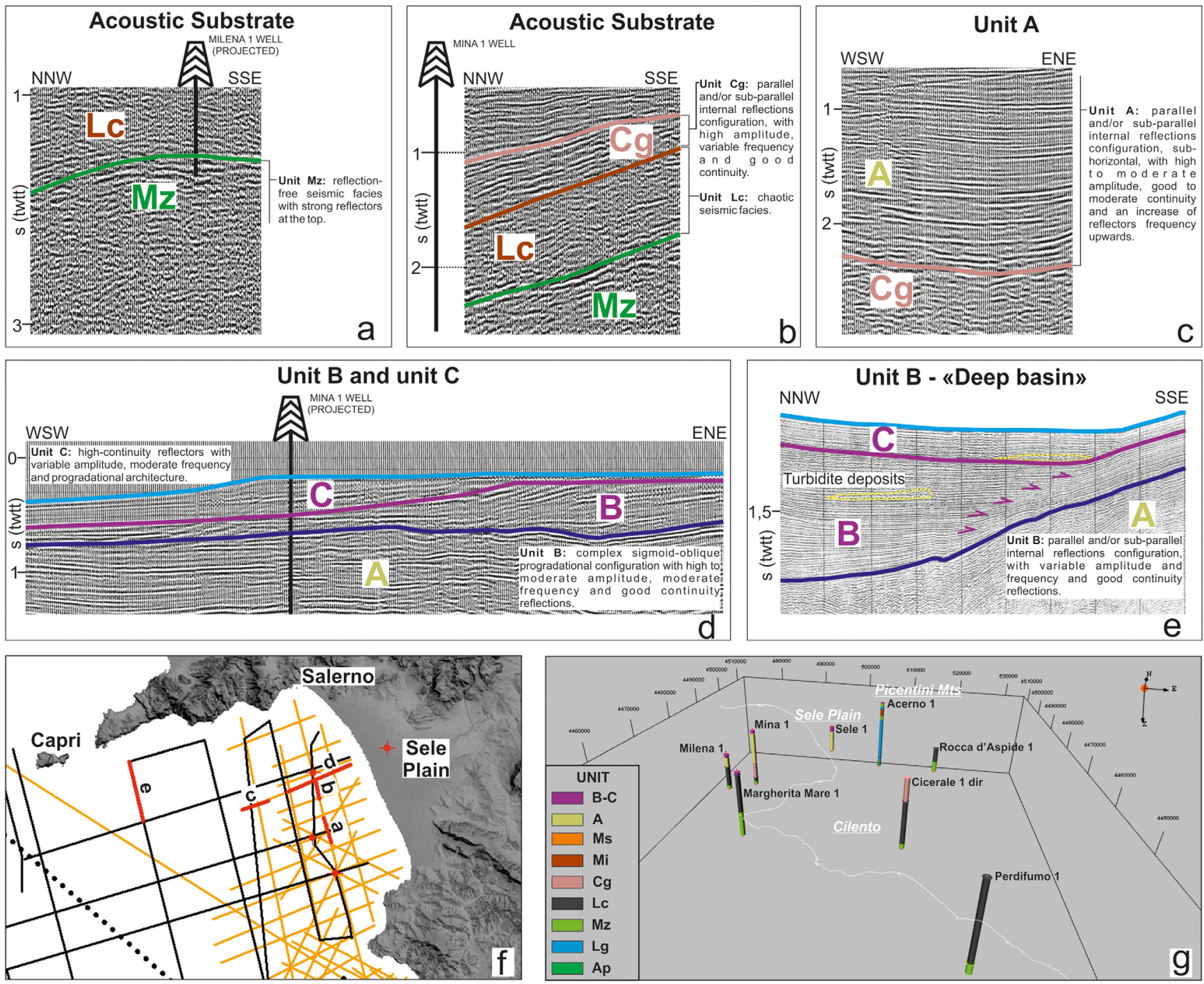

Fig. 5. (a-f) Interpreted seismic sections calibrated by well logs displaying the main seismic facies and the configuration pattern types in the stratigraphic infill of the Southern Campania Margin basins; (g) 3-D visualization of the stratigraphy of the wells. A = Unit A, $\mathrm{B}=$ Unit $\mathrm{B}, \mathrm{C}=$ Unit $\mathrm{C}, \mathrm{Ms}=$ Messinian deposits, $\mathrm{Mi}=$ Miocene deposits, $\mathrm{Cg}=$ Cilento Basin deposits, Lg = Liguride units, $\mathrm{Mz}=$ Apennine Platform unit, $\mathrm{Lg}=$ Lagonegro Basin units, Ap = Apulia Platform unit. The view is from southeast and the vertical scale is in meters.

of the Liguride and Sicilide basinal Units (Nord-Calabrese and Parasicilide Units; Knott, 1987; Bonardi et al., 1988; Cammarosano et al., 2004; Vitale and Ciarcia, 2013) Cretaceous-Lower Miocene in age cropping out at the Cilento Promontory and in the adjacent areas.

The Cg unit unconformably covers Lc unit and shows a parallel and/or sub-parallel internal reflection configuration with high amplitude, variable frequency and good continuity (Fig. 5). It corresponds to clays, marls, conglomerates and chalky limestones Upper Miocene in age drilled in the Mina 1 well (1013 m-thick); These deposits, that unconformably overly Lc unit, are equivalent of the Langhian-Lower Tortonian sediments of the Cilento Group (Cammarosano et al., 2004; Milia et al., 2017d and bibliography therein) cropping out at the Cilento Promontory. The strong and continuous reflectors within $\mathrm{Cg}$ unit are the seismic response of thick strata of marls and clays interlayered between clastic deposits.

Onshore deep wells in the Picentini Mts tectonic window (Fig. 2) encountered the external units of the Southern Apennines thrust belt. Indeed the Acerno well drilled, from upper to lower units (Fig. 4): Triassic dolomites of the Apennine Platform units, lower Trias-lower Cretaceous Lagonegro Basin units and lower Cretaceous limestones of the Apulia Platform unconformably overlain by Messinian evaporites. There is no proof of the development of these tectonic units in the SCM offshore and Cilento Promontory (Fig. 4). 


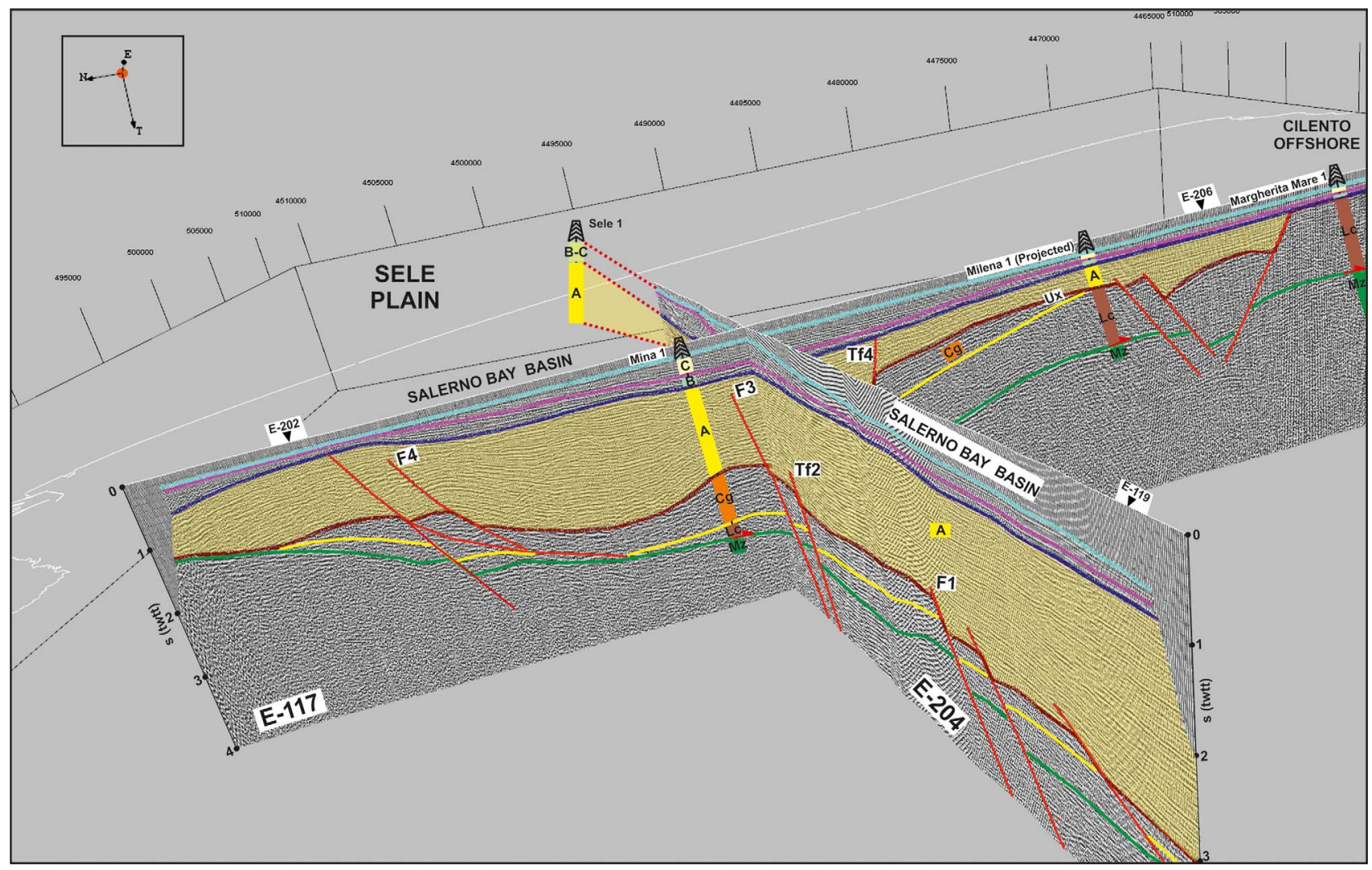

Fig. 6. 3-D visualization of the interpreted seismic sections E-117 and E-204 calibrated by well logs showing the stratigraphic infill of the Salerno Bay Basin (units A, B, C), overlying the acoustic substrate (units Cg, Lc and Mz). Normal faults (F1, F3, F4) and transfer faults (Tf2, Tf4) are also shown. The view is from west-southwest and the vertical scale is in seconds.

\subsection{Unit A (Lower Pleistocene)}

Unit A is a wedge-shaped seismic unit covering a large part of the SCM (Fig. 7a); it unconformably overlies the acoustic basement (unconformity Ux; Fig. 6) and is characterized by parallel and/or sub-parallel internal reflections configuration with high to moderate amplitude, good to moderate continuity and a vertical change of reflectors frequency: from low at the base to high at the top.

On the base of well logs stratigraphy and outcrops data it was possible to correlate Unit A to a couple of stratigraphic units made up of Lower Pleistocene (biozone MPL6) marly clays and marls interbedded with sands and polygenic conglomerates (drilled in Mina 1 and Milena wells; respectively 1084 m-thick and 490 m-thick; Fig. 4) covered by Lower Pleistocene (biozone post-MPL6) gravels interbedded with sandy clays (1157 m-thick in Sele 1 onshore well) passing laterally to marly clays interbedded with fine sands and abundance of carbonaceous materials (698 m-thick in Mina 1 offshore well). The younger stratigraphic unit can be correlated to the Lower Pleistocene (biozone post-MPL6) deposits and to gravels and polygenic conglomerates with sandy-silty matrix of the Eboli Supersynthem (CE) dated Lower Pleistocene (1.52-0.99 Ma; Cinque et al., 1988) cropping out on the hills bounding the Northern part of the Sele Plain.

Well and outcrop data indicate that unit A was deposited initially in a coastal-shallow water environment and then in a shelf environment; this stratigraphic evolution highlights a deepening of the basin that is confirmed by the wedge shape of the unit A (Fig. 8) linked to a first extensional tectonic stage (see below). The isopach map of the unit A (Fig. 7a) features two thickness maxima $(>2100 \mathrm{~m})$ : one is located in the area of the SBB-Mina 1 well (geological section a1) and another in the CB (geological section a2).

\subsection{Unit B (Early Middle Pleistocene)}

Unit B overlies Unit A and represents the intermediate unit of the stratigraphic succession of the SCM. It is characterized by a complex sigmoid-oblique progradational configuration with high to moderate amplitude, moderate frequency and good continuity reflections; this configuration indicates aggradation/progradation of the sediments from the coast toward the sea during a relative tectonic stability of the area (Fig. 5). In contrast, in the deep basin, unit B shows a parallel and/or sub-parallel internal reflections configuration with variable amplitude and frequency and good continuity reflections (Fig. 5) indicating the deposition of pelagic/hemipelagic sediments interbedded with turbidites. The convergence of reflectors and the onlaps termination southeastwards and a gradual thickness increasing northwestwards (Fig. 5) can be linked to the syn-depositional activity of the Sorrento Peninsula Fault system (Milia and Torrente, 1999). This unit corresponds 

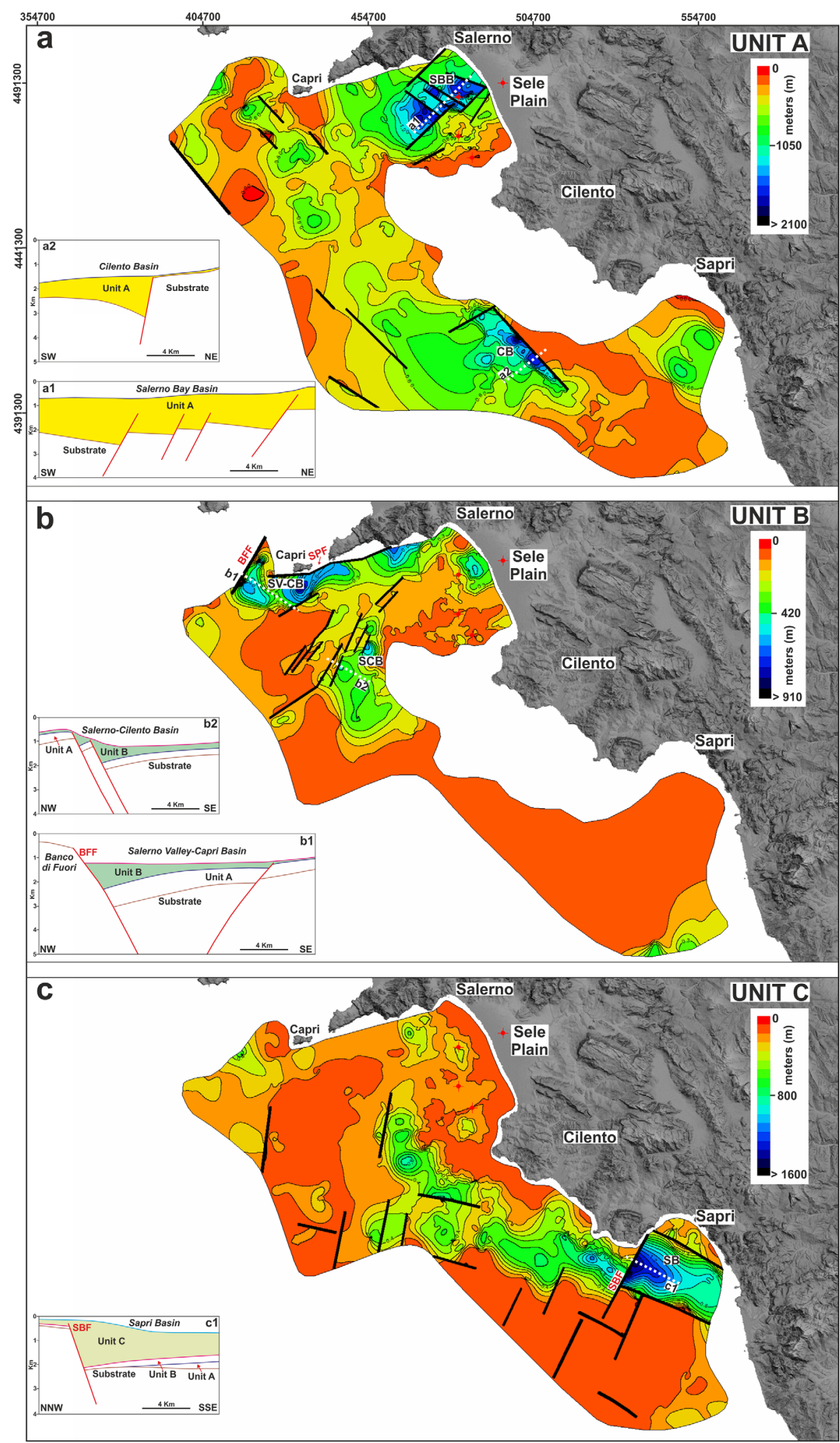

Fig. 7. (a) Isopach map of the Unit A and geological sections (a1 and a2) through the Salerno Bay Basin (SBB) and Cilento Basin (CB). Faults are Lower Pleistocene in age. Contour interval is $150 \mathrm{~m}$. (b) Isopach map of the Unit B and geological sections (b1 and b2) through the Salerno Valley-Capri Basin (SV-CB) and Salerno-Cilento Basin (SCB). BFF = Banco di Fuori Fault, $\mathrm{SPF}=$ Sorrento Peninsula Fault. Faults are early Middle Pleistocene in age. Contour interval is $70 \mathrm{~m}$. (c) Isopach map of the Unit C and geological section (c1) through the Sapri Basin (SB). SBF = Sapri Basin Fault. Faults are Late Middle PleistocenePresent in age. Contour interval is $100 \mathrm{~m}$. Maps coordinate system: UTM, WGS84. 
to the gravels, sands, clays and marly clays Middle Pleistocene in age drilled in Sele 1, Mina 1, Milena 1, Margherita Mare 1 wells (respectively 340, 186, 175, 130 m-thick). The isopach map of the unit B (Fig. 7b) shows two thickness maxima (>900 m): the first one is located in the SV-CB (geological section b1) and the second one in the SCB (geological section b2).

\subsection{Unit C (Late Middle Pleistocene to present)}

Unit $\mathrm{C}$ is the uppermost unit of the stratigraphic succession of the SCM and displays a progradational architecture with high-continuity reflectors, moderate frequency and variable amplitude (Fig. 5d). The toplap surface of the prograding unit $\mathrm{C}$ forms the present continental shelf of the SCM (Figs. 5d and 7c). In contrast, in the deep basin, this unit shows a parallel and/or sub-parallel internal reflections configuration with variable amplitude and frequency and good continuity reflections (Fig. 5e).

Based on wells and outcrop data it is possible to correlate units B and C to gravels, sands, clays and marly clays of the Battipaglia-Persano Supersynthem Middle Pleistocene in age (Amato et al., 1991), drilled in offshore and onshore wells (Fig. 4) and cropping out in the Sele Plain. Unit C in the SBB and SCB is characterized by a thick regressive succession (up to $800 \mathrm{~m}$ ) and its seaward lateral migration indicates a period of relative tectonic stability (Figs. 6 and 5d).

The isopach map of unit $\mathrm{C}$ (Fig. 7c) shows two thickness maxima: the first one (800-1100 m) off Cilento Promontory, roughly parallel to the coast, that reflects the shelf margin of the coastal progradation; and the second one $(>1600 \mathrm{~m})$ in the SB (geological section $\mathrm{c} 1$ ). Unit $\mathrm{C}$ of the SCM is physically continuous with unit $\mathrm{C}$ of the Northern Campania Margin characterized by 4 th order sequences and dated post-04 Ma (Milia and Torrente, 1999).

\subsection{Depth conversion}

Based on the mean values of $\mathrm{P}$-waves velocities $\left(V_{\mathrm{p}}\right)$ obtained from sonic log of the Milena 1 well and the interval velocities $\left(V_{\text {int }}\right)$, a four-layers velocity model has been adopted for the seismic depth conversion (Fig. 9): $V_{\mathrm{p}}$ values of $1500 \mathrm{~m} / \mathrm{s}, 2000 \mathrm{~m} / \mathrm{s}, 3700 \mathrm{~m} / \mathrm{s}$ and $5700 \mathrm{~m} / \mathrm{s}$ were assigned, respectively, to sea water, Quaternary deposits (units A, B and C), Ligurian Accretionary Complex-Cilento Group (units Lc and Cg) and Apennine Platform Unit (unit $\mathrm{Mz}$ ). Our model is certainly oversimplified and not completely realistic, in fact the lithology of the recent sediments is quite variable, and their compaction and velocity are a function of depth. Nonetheless, the resulting geological sections based on the depth conversion of the seismic profiles are valuable to analyze the spatial relationships between the geometries of the basin infill and the extensional boundary faults.

\section{Quaternary tectonics}

The interpretation of the seismic reflection profiles calibrated by wells, the generation of 2-D and 3-D models of the geological surfaces (stratigraphic horizons and faults) and the isopach maps of the stratigraphic units supply first-order constraints for a multi-stage tectonic model of the SCM. The analysis of the interplay between stratigraphic infill and faulting permitted us to assign an age to faults. In particular, the Quaternary tectonic evolution of the Southern Campania Margin is polyphased and controlled by major faults (normal faults and strike-slip/transfer faults) that bound several sedimentary basins (SBB, SV$\mathrm{CB}, \mathrm{SCB}, \mathrm{CB}$ and SB basins) (Figs. 3 and 7).

\subsection{First tectonic stage: Lower Pleistocene}

In the SCM the deposition of unit A (Lower Pleistocene) (Fig. 7a) was mainly controlled by NW-trending normal faults and NE-SW strike-slip/transfer faults associated to the first tectonic stage responsible of the formation of two up to 2100-thick basins: Salerno Bay Basin (SBB) and Cilento Basin (CB). The SBB covers an area of approximately $365 \mathrm{~km}^{2}$ and is characterized by an array of NW-trending normal faults (F1, F3, F4; Figs. 6, 8) that downthrow up to $2800 \mathrm{~m}$ the Meso-Cenozoic substrate south-westwards generating tilted blocks/half grabens structures (Fig. 8). These normal faults end abruptly toward northwest and southeast against NE-trending high-angle strike-slip/transfer faults (Tf1, Tf2, Tf3, Tf4; Figs. 6 and 8). The CB, located on the slope in the Cilento Promontory offshore, covers an area of approximately $345 \mathrm{~km}^{2}$ and trends NW-SE (Fig. 3). The NW-trending normal fault, responsible for the basin formation, displays planar geometry and features a maximum throw of 2000 $\mathrm{m}$ of the Meso-Cenozoic substrate. This latter ends abruptly toward northwest against a NE-trending highangle strike-slip/transfer fault $\left(\mathrm{Tf}_{\mathrm{CB}}\right)$. Besides, other NW-trending normal faults affected the SCM during the Lower Pleistocene, controlling the distribution of minor depocenters (Fig. 7a). The wedge-shaped geometry that often characterizes Unit A is linked to syn-depositional activity of NW-trending normal faults (Fig. 8).

The combined interpretation (Fig. 10) of the CROP M6B seismic profile, calibrated by the ODP Site 650, and the multibeam map of the Tyrrhenian Sea (Marani et al., 2004) documented that the first rifting stage of the SCM developed until the bathyal area. Indeed, this seismic profile displays an array of NW-SE normal faults (Sartori Lineament) bounding the Marsili Basin (Fig. 11; F14, F15, F16) that downthrow the substrate at depth greater than $3800 \mathrm{~m}$ and can be dated Lower Pleistocene.

\subsection{Second tectonic stage: Early Middle Pleistocene}

During the second tectonic stage (0.7-0.4 Ma) the SBB is characterized by the deposition of the Unit B during low to moderate symmetrical subsidence with sediments that prograde from the coast toward the sea filling the depocenters (Figs. 5, 6 and 7b). Simultaneously, it started the formation of two half-graben featuring asymmetrical high subsidence controlled by NE-SW normal faults (Figs. 3 and 7b): Salerno Valley-Capri Basin (SV-CB) and Salerno-Cilento Basin (SCB). The SV-CB, trending ENE-WSW, covers an area of approximately $450 \mathrm{~km}^{2}$ and is controlled by two main NE-trending normal faults: 


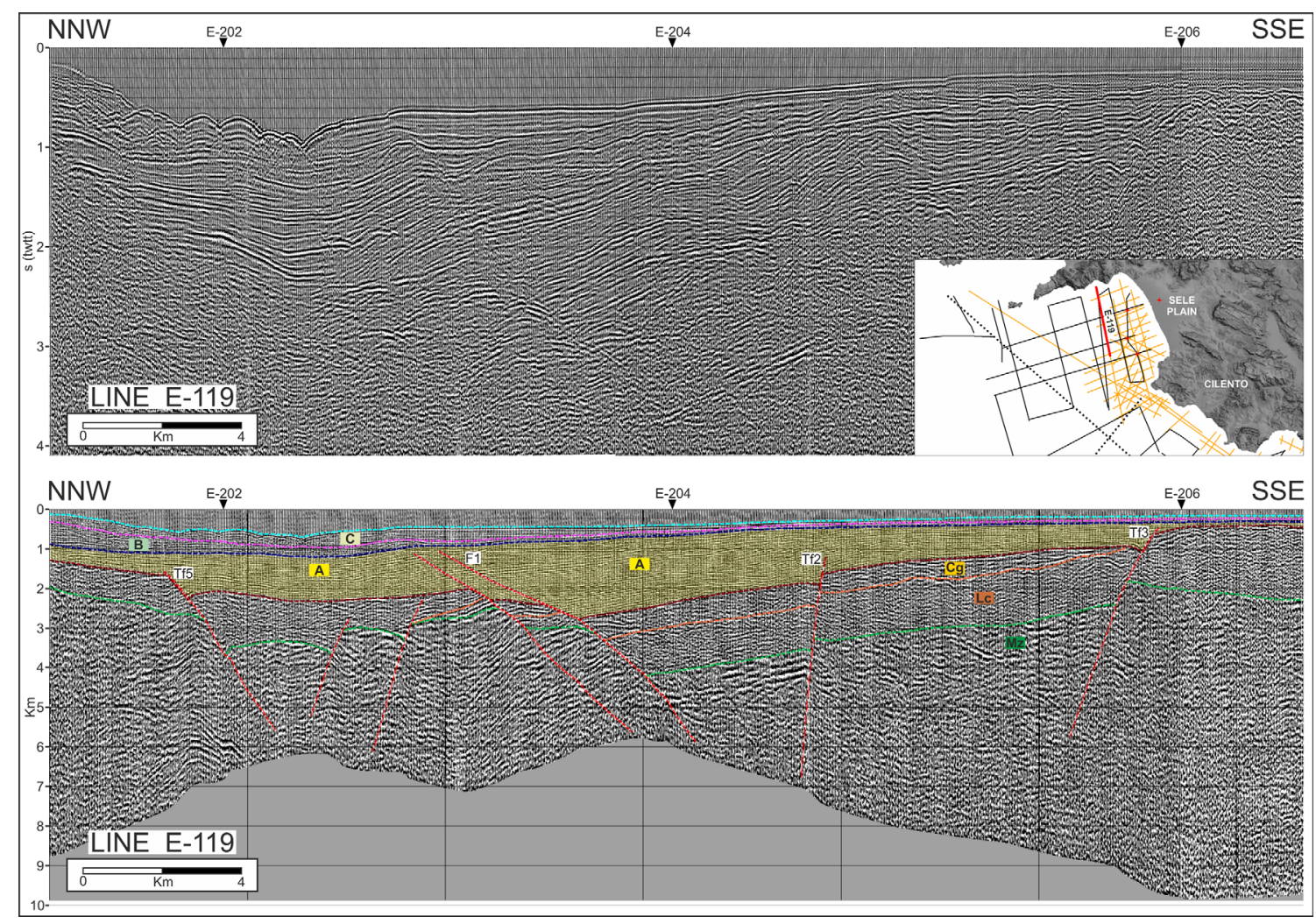

Fig. 8. The seismic image and interpreted depth-converted profile for line E-119. The line t shows the Meso-Cenozoic substrate (units $\mathrm{Cg}, \mathrm{Lc}$ and $\mathrm{Mz}$ ) overlain by units $\mathrm{A}, \mathrm{B}$, and $\mathrm{C}$ and several normal and transfer faults (F1, Tf2, Tf3, Tf5).

the Sorrento Peninsula Fault (SPF) and the Banco di Fuori Fault (BFF; Figs. 7b and 11a) that downthrow the top of unit A at $2200 \mathrm{~m}$ south-eastwards (Fig. 11a). The SCB, located on the slope, is NNE-SSW elongated and extends over an area of approximately $120 \mathrm{~km}^{2}$ (Figs. 3 and $7 \mathrm{~b}$ ); the formation of the asymmetrical SCB is linked to an array of NE-trending normal faults that downthrow the top of unit A at $2000 \mathrm{~m}$ south-eastwards. Another picture of the SV-CB and SCB half-grabens is provided by the CROP M36 seismic profile (Fig. 11a), that runs from the Capri Island offshore to the Policastro Bay, that shows asymmetrical fault blocks dipping northwestward bounded by NEtrending normal faults and a main angular unconformity between units $\mathrm{A}$ and $\mathrm{B}$ that marks the tilting of the fault blocks. Thus, NE-trending normal faults, characterized by asymmetric style, control the map distribution of the tectonically enhanced unconformities and syn-kinematic sedimentary wedges.

\subsection{Third tectonic stage: Late Middle Pleistocene to present}

In the last tectonic stage (post-0.4 Ma), NW-SE transfer zone, featuring restraining and releasing bends, and several NNE-trending normal faults developed in the SCM (Figs. 3 and $7 \mathrm{c}$ ).

In particular, in the Policastro Bay, a NNE-trending normal fault (Sapri Basin Fault) controlled the genesis and evolution of the SB (maximum thickness $>1600 \mathrm{~m}$ ), elongated in a WNW-ESE direction and extended approximately $460 \mathrm{~km}^{2}$. It is bounded toward North-East and South-West by a couple of NW-trending high-angle strike-slip transfer faults; the strike-slip kinematics of these faults is suggested by the striking different seismic features of the North-Northeast and south-southwest fault blocks. The Sapri Basin Fault (SBF) forms tilted block/half graben structure; besides, the wedge-shaped geometry that characterizes the youngest unit $\mathrm{C}$ (post-0.4 Ma) in the SB is the testimony of the syn-depositional activity of this fault (geological section c1; Fig. 7c).

In the Cilento offshore a folded and faulted stratigraphic succession highlights the existence of a wide deformation zone, approximately trending E-W (Figs. 10 and 11). This deformation zone, going southwards has been interpreted as a restraining band and a releasing band of a basement strike-slip fault zone. In particular, folds and flexural arching, converging to a main vertical fault, visible in the CROP M36 and CROP M6B seismic profiles, can be linked to a positive structural inversion, while a negative flower structure occurs in the Southern part of CROP seismic profile M36.

The analysis of the interplay between stratigraphic infill and deformation structures permitted us to assign a post$0.4 \mathrm{Ma}$ age to the faults of third stage. Indeed, in the Cilento offshore, in agreement with Ferraro et al. (1997), the strata of the youngest unit C (Late Middle Pleistocene-Present) result extensively folded and faulted. 


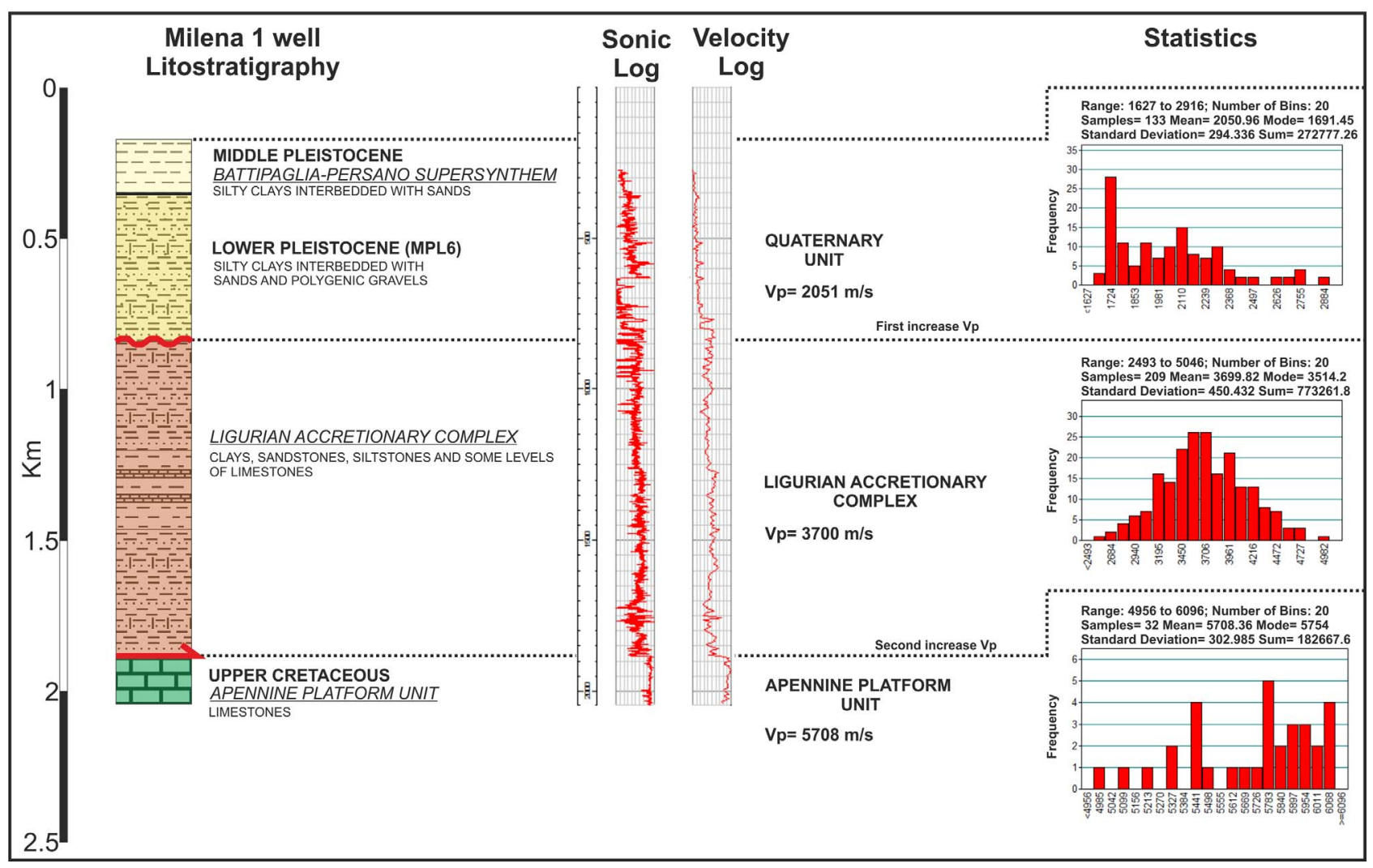

Fig. 9. Lithological, sonic $\log$ and velocity $\log$ of Milena 1 well (see Fig. 1b for location). The right panel displays a statistical analysis of the velocities of the Quaternary Unit, Ligurian Accretionary Complex and Apennine Platform Unit.

\section{Quantification of extension and normal faults architecture}

The style of the extensional normal fault systems of the SCM is a matter of debate. Low-angle normal fault placing younger-on older rocks the Apennines platform succession and transcurrent faults have been mapped onshore, eastward of the Sorrento Peninsula in the Picentini Mts (Casciello et al., 2004). These low-angle normal faults have been interpreted as the result of extensional tectonics (Oldow et al., 1993) or associated to strike-slip faulting (Schiattarella, 1996). Unfortunately the absence of syntectonic deposits does not allow to constrain the age to this tectonic event. High angle normal faults attributed to the Lower Pleistocene (younger than 2.0 Ma) have been recognized along the Campania margin and onshore. They produced graben structures filled by clastic sediments (Campania Plain, Sele Plain and Vallo di Diano; Gars and Lippman, 1984; Milia and Torrente, 1999, 2015a; Amicucci et al. 2008). Besides the data presented in this paper and several regional geological sections (e.g. Mostardini and Merlini, 1986; Menardi-Noguera and Rea, 2000; Milia et al. 2013, 2017c; Vitale and Ciarcia 2013) document that Southern Apennines thrusts are displaced by Quaternary normal faults linked to the Tyrrhenian rifting. The estimate of extension the SCM is important to constrain the kinematics of Eastern Tyrrhenian Margin and to enable comparisons with other extensional margins in similar tectonic settings. Section balancing normally involves the assumption of plane-strain deformation with the extension direction being parallel to the chosen section (e.g. Gibbs, 1983; Rowan and Kligfield, 1989). Furthermore, the slip directions on the faults that intersect the section should ideally be parallel to the section line. In order to evaluate the amount of extension $\left(e=L_{0}-L_{\mathrm{f}}=L_{0}\right)$ of the SCM we balanced and restored two geological sections (constructed from the depth-converted seismic profiles) across the sedimentary basin depocenters and boundary faults (Fig. 12). The chosen section lines (NE-SW and NW-SE) are parallel to the slip direction of the normal faults of the Campania margin (Gars and Lippman, 1984; De Rita and Giordano, 1996; Milia and Torrente, 1997). The first section (geological section a1) crosses the SBB and displays four normal faults with intermediate dip and different separation of the Mesozoic-Cenozoic substrate. $L_{0}(20.55 \mathrm{~km})$ is the original length of an erosional surface, formed during the Pliocene-Lower Pleistocene, affecting the deformed Mesozoic-Cenozoic substratum, and $L_{\mathrm{f}}$ is its present length $(23 \mathrm{~km})$. The calculated value of extension along the cross section a1 is thus $e=0.12$. The second section (geological section b1) is transversal to the SV-CB basin and characterized by a main normal fault $(\mathrm{BFF})$ with a listric geometry and a minor antithetic fault, $\left(\mathrm{F}_{\mathrm{A}}\right)$ that displace unit A and the Mesozoic-Cenozoic substrate. The recorded extensional strain of the second section results $e=0.18$, slightly higher than that of the first section. 


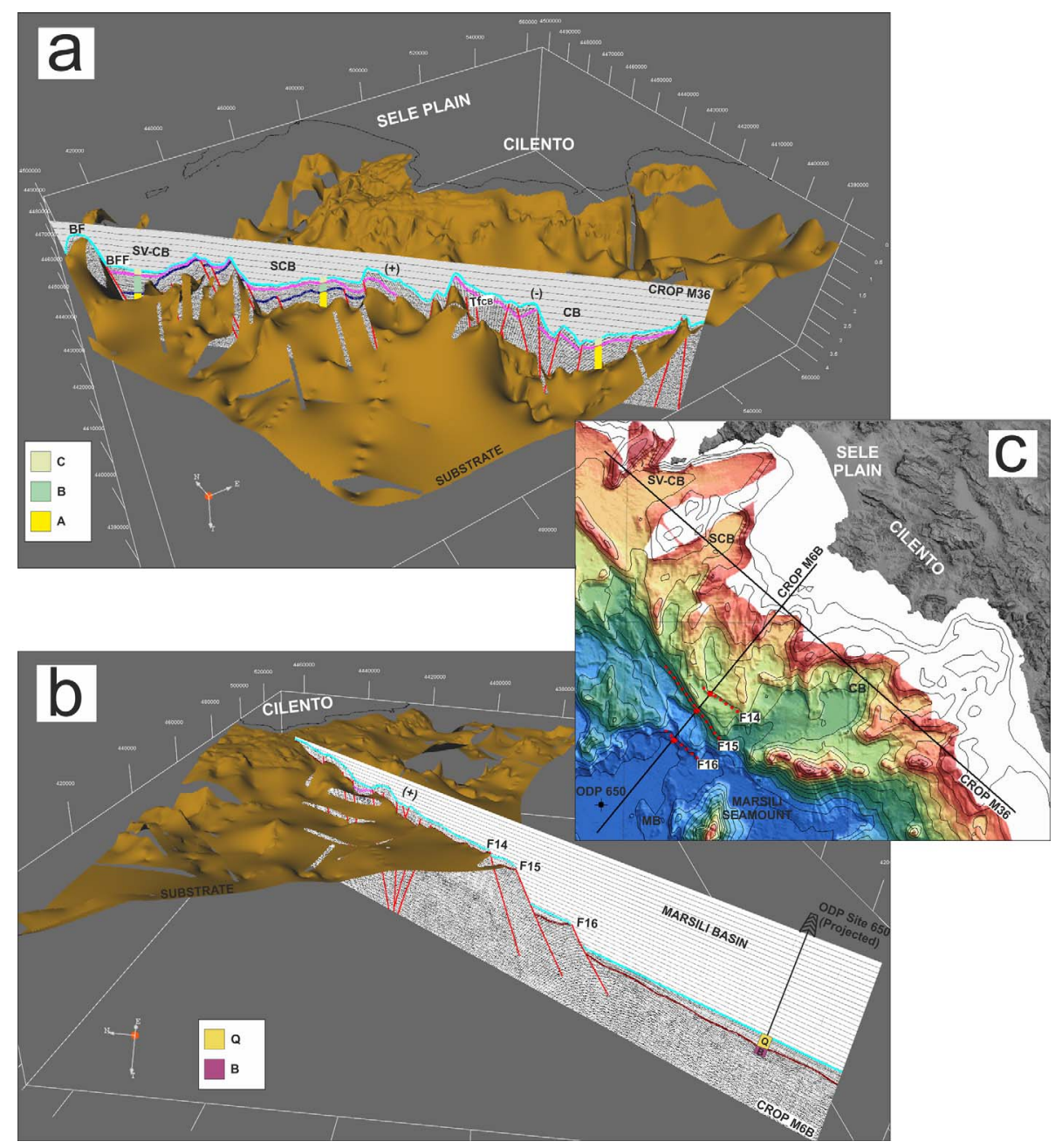

Fig. 10. (a, b) 3-D digital model inserted into the spatial-oriented grid of the SCM substrate and 3-D visualization of the interpreted seismic sections CROP M36 and CROP M6B. The view is from south-west and the vertical scale is in seconds. A = Unit A, B = Unit $\mathrm{B}, \mathrm{C}=$ Unit $\mathrm{C}, \mathrm{BF}=$ Banco di Fuori, BFF $=$ Banco di Fuori Fault, TfCB = transfer fault Cilento Basin, SV-CB = Salerno ValleyCapri Basin, SCB = Salerno-Cilento Basin, CB = Cilento Basin, $\mathrm{Q}=$ Quaternary deposits, $\mathrm{B}=$ basalts, $(+)=$ restraining bend, $(-)=$ releasing bend. The seismic section M6B shows that the boundary between the Marsili Basin and the SCM corresponds to normal faults escarpment (F14, F15, F16; Sartori Lineament). (c) Multibeam map of the Tyrrhenian Sea from Marani et al. (2004).

The construction of balanced sections and the balancing and restoration of key horizons permitted us to recognize the accurate geometry of the faults and compute amount of extensions of the SCM ranging between 0.18 and 0.12 . The Quaternary extension estimates presented here are likely to be minimum estimates. Indeed, further contributions to extension not considered in this study are: additional small-scale subseismic faults (not recognizable due to limitation in seismic resolution); the inclined internal shear deformation rather than the vertical shear assumed in the restoration model; even if there is no direct evidence, a local reactivation of the older detachment surfaces.

The SCM extension values are finally comparable to those calculated for other sectors of the Tyrrhenian margin ( $e=0.11$, Pepe et al., 2000; $e=0.26$, Milia et al., 2003) and further extensional regions worldwide $(e=0.19$, North Sea; Rouby et al., 1996).

\section{Tectono-stratigraphic evolution of the Southern Campania Margin and constrains for the migration of the Calabria Terrane}

The Southern Campania Margin represents a key area for the knowledge of the geological evolution of the Central Mediterranean because it records a middle-upper Miocene extension stage and displays the whole nappe pile affected by Pliocene-Quaternary multiple rifting events. The overall tectonic events recognized in SCM have been framed in a paleogeographic framework started since Oligocene times (Fig. 13).

The SCM is characterized by the lateral juxtaposition of several tectonic units of the Southern Apennines thrust belt pertaining to different paleogeographic domains. Approximately $20 \mathrm{~km}$ away from the Tyrrhenian coast at Picentini 


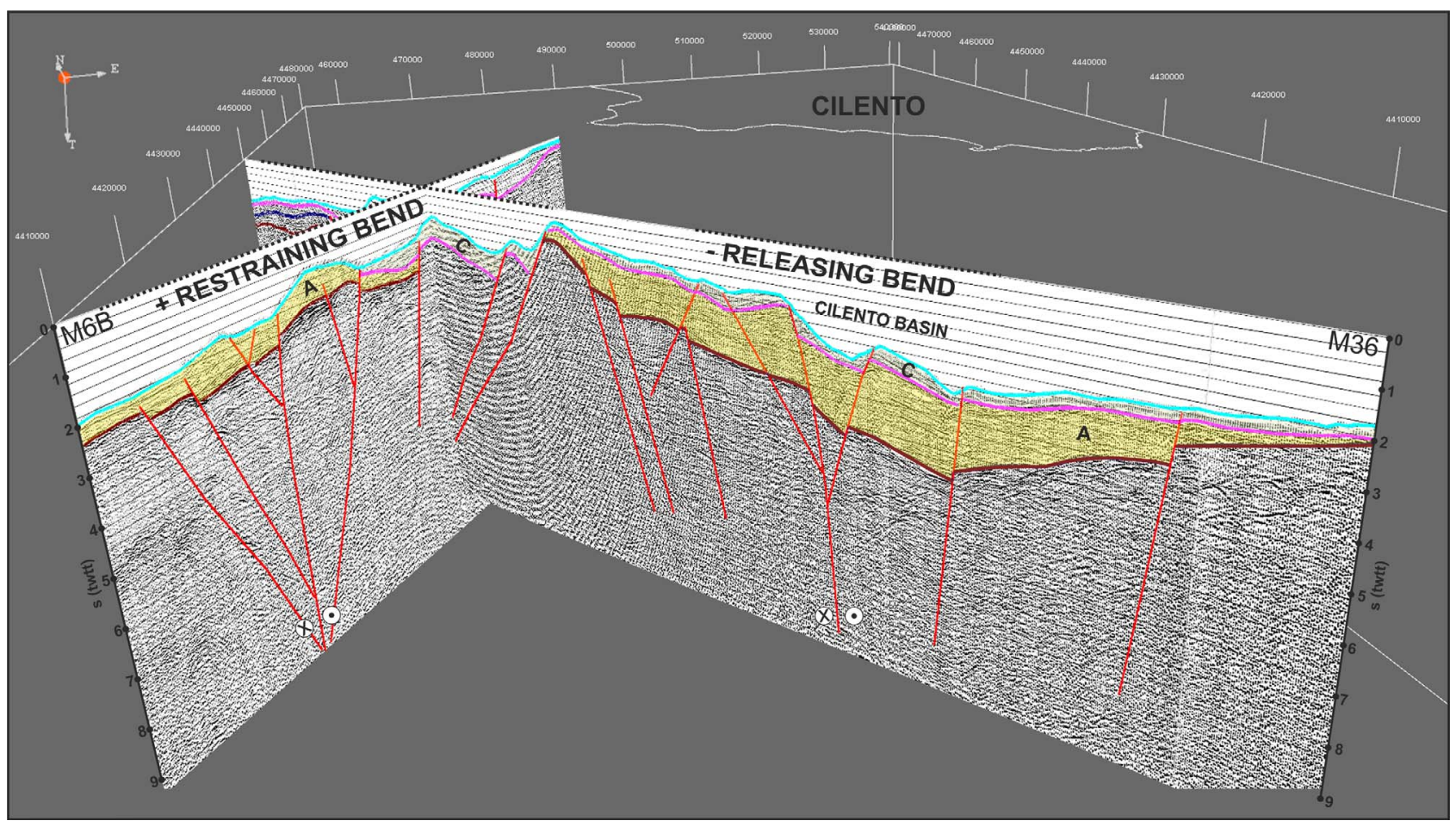

Fig. 11. Interpreted seismic sections CROP M36 and M6B showing a wide deformation zone linked to a positive structural inversion and negative flower structure. The view is from south and the vertical scale is in seconds.

Mts (Acerno well) several nappes of the Lagonegro Basin overly the Apulia Platform unit at depth of $\sim 4 \mathrm{~km}$. On the contrary on the Tyrrhenian side (SCM offshore and Cilento Promontory) only Liguride thrust sheet overly the Apennine Platform units. These remarkable differences in the stratigraphic succession are due to the different paleogeographic positions of the Liguride Basin and the Lagonegro Basin. As a matter of fact, the Liguride units formed in an oceanic domain and are the substrate of the Cilento Basin, as the Lagonegro units formed in basinal domain close to the Apulia Platform.

These peculiar geological features of the thrust belt and rift zones are not in agreement with a simplistic model of progressive eastward migration of both Southern Apennines' thrust fronts and Tyrrhenian Sea extension. Indeed the paleogeographic map at approximately $30 \mathrm{Ma}$ (Fig. 13a) shows the Liguride Basin in the Northern part of the Central Mediterranean area, offshore Corsica and the Lagonegro Basin in the south-east, between Adria and the Appennine Platform. The successive opening of the Provençal-Balearic backarc basin led to a counterclockwise rotation of the Sardinia-Corsica block, and involvement of the Ligurian Ocean in the accretionary prism until the lower Langhian, with formation of Liguride thrust sheets superposed on the Apennine-Apulia Platform domain.

During the onset (lower Serravallian-Upper Tortonian) of the Central Mediterranean forearc extension (early stage of the Tyrrhenian opening) several transtensional/extensional basins (including the Cilento Basin) formed on the thrust belt (Fig. 13b). These basins migrated east-southeastwards contemporaneously to a progressive lateral shifting of the Liguride-Apennine Platform nappes towards the
Lagonegro Basin. In the Southern Apennines fold-andthrust belt, thermal indicators record $<10$ Ma exhumation of sedimentary units from depths locally in excess of $5 \mathrm{~km}$ (Schiattarella et al., 2006; Mazzoli et al., 2008). Schiattarella et al. (2006) hypothesized in Tyrrhenian side of the Southern Apennines chain an extensional tectonics event younger than upper Tortonian and older than Pliocene. Besides proofs of Messinian extension are documented by the Stilo supradetachment basin (Calabria offshore) that records an increase in extensional rate and isostatic and flexural uplift (Milia and Torrente, 2015b). Within this geological framework we postulate that the low-angle normal faults present onshore of the SCM were possibly associated to the Messinian forerarc extension.

It is important to outline that the thick silicoclastic Cilento succession, characterized by an oceanic substrate, was fed by the uplift and erosion of crystalline units, thus suggesting a middle-upper Miocene paleogeographic position of the Cilento Basin close to the Calabria terrane (e.g. Critelli and Le Pera, 1994; Milia et al., 2017d).

The Pliocene epoch marks the onset of the breakup of the Tyrrhenian rift with the opening of the Vavilov Basin (Fig. 13c), where mantle rocks were exhumed west of the SCM and Calabria terrane (Milia et al., 2013, 2017c). Contemporaneously, the Southern Apennines allochthonous nappes thrusted toward $\mathrm{NE}$ for several tens of $\mathrm{km}$ over the lower Pliocene deposits covering the parautochthonous structures of the Apulia Platform (Mostardini and Merlini, 1986; Monaco et al., 2001). The lower Pliocene-Lower Pleistocene Crotone Basin, overlying the Northern Calabria subterrane is characterized by extensional block faulting and uplift followed by rapid subsidence, (Mellere et al. 2005; 
a)
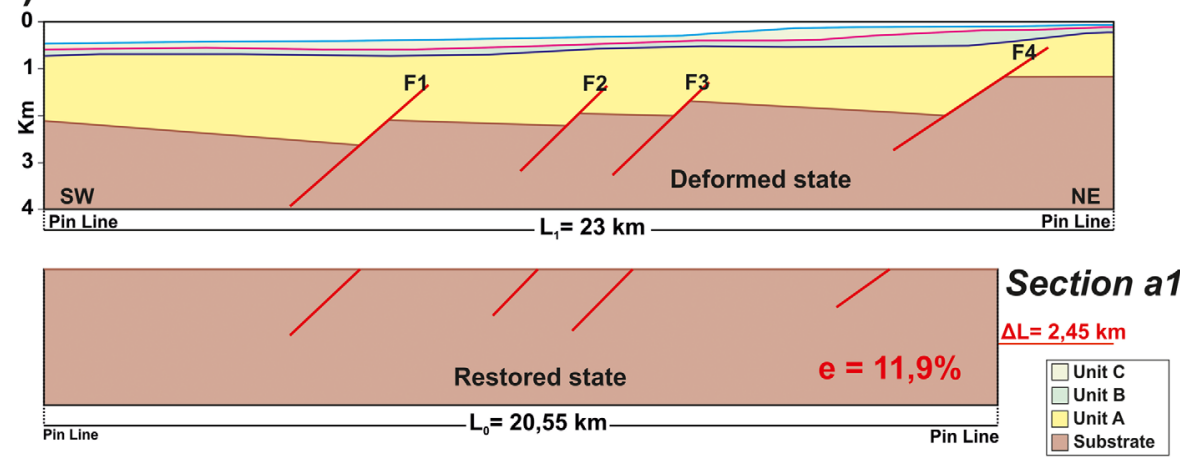

b)
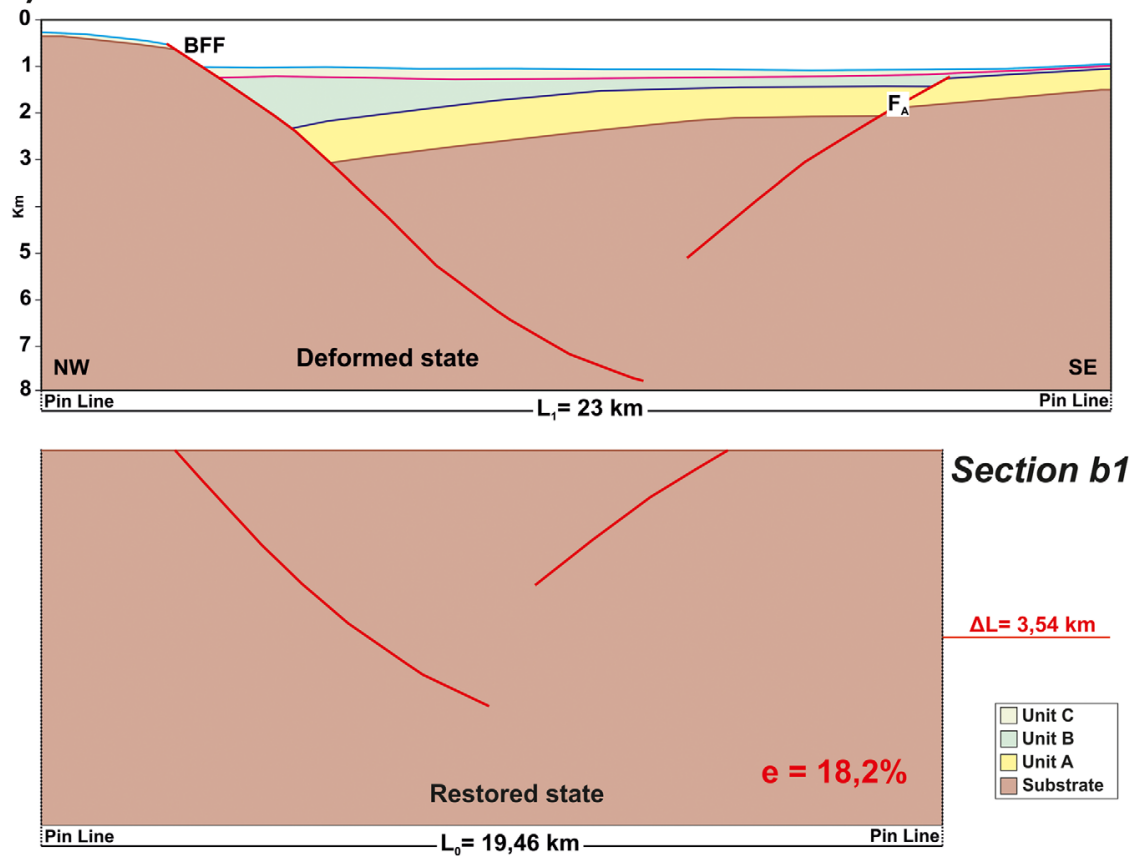

Fig. 12. (a) Balanced and restored cross section a1 in the Salerno Bay Basin; section location in Figure 7. (b) Balanced and restored cross section b1 in the Salerno Valley-Capri Basin; sections location in Figure 7.

Massari and Prosser 2013; Zecchin 2005). The interpretation of the Crotone Basin in the framework of extensional basins formed eastwards of the Vavilov Basin (Milia et al., 2017b), is coherent with the position of the Calabria terrane close to the uplifted Cilento promontory (Fig. 13c).

At the beginning of the Pleistocene the Tyrrhenian rifting migrated eastwards in the Campania margin and Marsili Basin (Torrente and Milia, 2013; Milia and Torrente, 2015a; Milia et al., in press) (Fig. 13d). The first Quaternary rifting phase, Lower Pleistocene in age (between 2.1 and 1.0 Ma), of the SCM affected mainly the Salerno Bay Basin where extension is documented by NW-trending faults bounding a preserved $1100 \mathrm{~m}$-deep depression. Contemporaneously marine sediments were deposited in the Crotone Basin (Suc et al., 2010).

Between the first and second rifting stages of the SCM, a late Lower Pleistocene tectonic event affected the Tyrrhenian margin and the Northern boundary of the Calabrian terrane. This event was associated to: i) end of the continen- tal collision and lock of Southern Apennines thrust belt toward the Apulia foreland and contemporaneous translation of the Calabria terrane toward the Ionian oceanic foreland; and (ii) triggering of a wide NW-SE region of left-lateral faulting (Pollino shear zone), transtensional zones, and local popup structures, in the Southern Apennines and Tyrrhenian back-arc margin (Knott and Turco, 1991; Monaco et al., 2001; Schiattarella et al., 2005; Milia et al., 2009, 2017a, 2017b). Patacca et al. (1990) dated this event to the Emilian-Sicilian boundary, an interpretation matched by Mattei et al. (2007), who placed the end of contraction at $\sim 1 \mathrm{Ma}$, as proved by sealing of deformation by sediments of Sicilian age.

In the early Middle Pleistocene the second extension event of SCM produced NE-ENE trending normal faults and extensional basins corresponding to underfilled halfgrabens (Salerno Valley-Capri Basin and Salerno-Cilento Basin). This period records an abrupt change of direction of extension (from NE-SW to NW-SE) in the eastern 

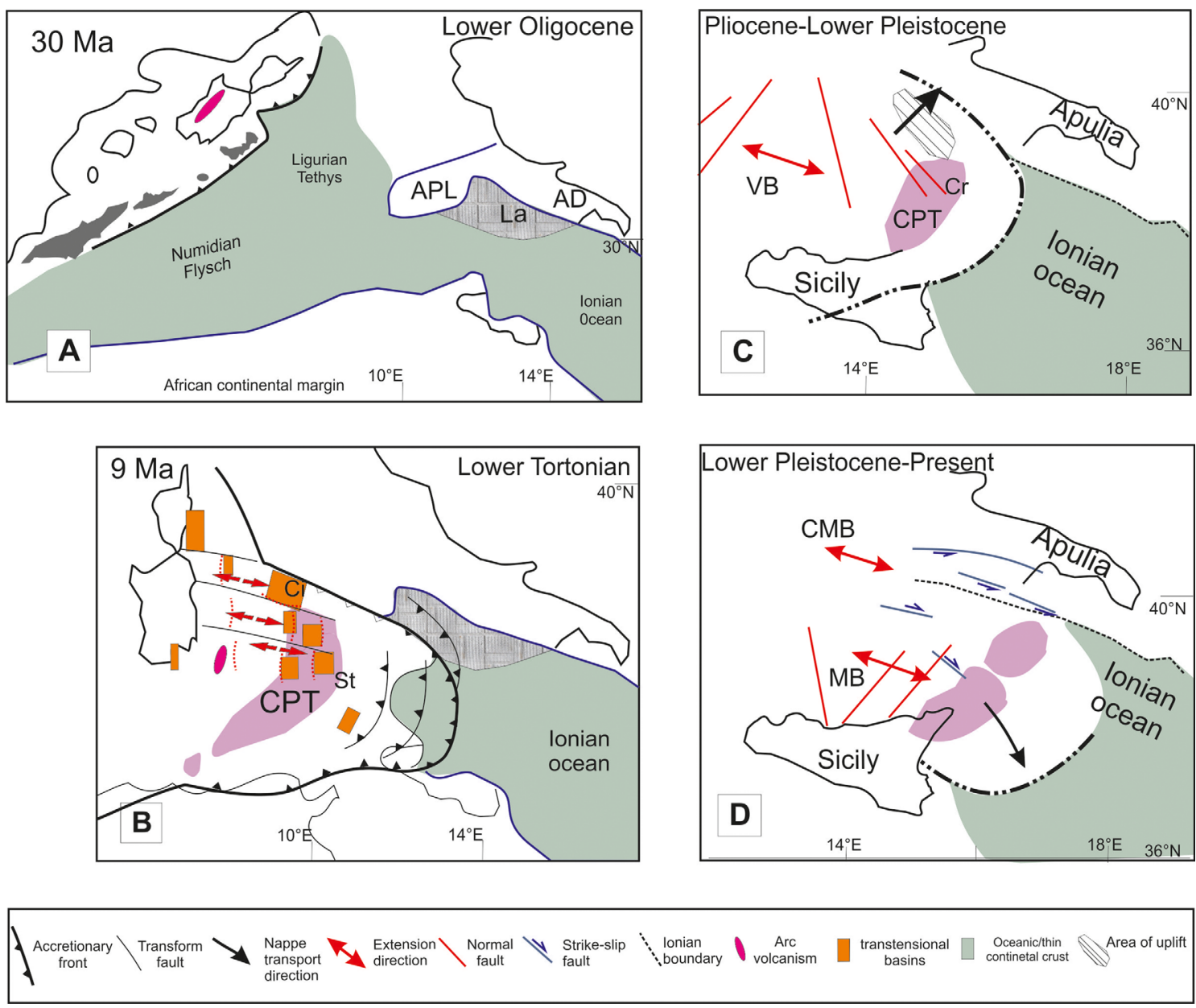

Fig. 13. Kinematic sketch of the Central Mediterranean orogenic system over the last 30 Ma, including nappe's transport direction, extension direction, and strike-slip faults. Just the faults related to each tectonic stage are indicated. APL = Apennine Platform, $\mathrm{La}=$ Lagonegro Basin, $\mathrm{AD}=$ Apulia Platform, CPT $=$ Calabria-Peloritani Terrane, $\mathrm{Ci}=\mathrm{Cilento}$ Basin, VB $=\mathrm{Vavilov}$ Basin, $\mathrm{MB}=$ Marsili Basin, $\mathrm{CMB}=$ Campania Margin Basin, $\mathrm{Cr}=$ Crotone Basin, St = Stilo Basin. Modified after Milia et al. (2013, 2017a, 2017b, 2017c, 2017d, in press), Turco et al., 2013, van Hinsbergen et al. (2014), Milia and Torrente (2015a) and Malusà et al. (2016).

Tyrrhenian margin, associated to the change of direction of the tectonic transport (from NE to SE) of the Southern Apennines thrust belt (Patacca et al., 1990). During this stage were still active NW-SE strike slip faults in the Apennines (Catalano et al., 2004; Schiattarella et al., 2005) and NW-SE transfer zones in the Eastern Tyrrhenian Margin (Milia et al., 2009).

In the Late Middle Pleistocene to Present (post-0.4 Ma) extensional basins (e.g. Sapri Basin) and transfer zones formed in the SCM. Indeed NNE-trending normal faults developed coherently with the migration of the Calabrian accretionary prism toward the E-SE. During this tectonic stage, a NW-SE transfer zone, featuring restraining and releasing bends, formed off Cilento Promontory. The Northern Campania Margin was instead characterized by reactivation as oblique faults of preexisting structures (Milia and Torrente, 2011).

Milia, Iannace, Tesauro and Torrente (2017a) proposed a link between the evolution of upper plate over the last $1 \mathrm{Ma}$ and the onset and development of a STEP
(Subduction-Transform-Edge-Propagator) fault along the Northern margin of the Ionian slab.

\section{Conclusion}

We combined the analysis of seismic reflection profiles, borehole data, depth conversion, 3D models, balanced sections, and correlation with onshore and offshore documented geologic features to reconstruct the 3D architecture and evolution of the SCM and furnish age constrains for the migration of the Calabria terrane. From the results obtained we conclude that:

- The SCM records the oldest extensional /transtensional phase of the opening of the paleo-Tyrrhenian basin documented by the Langhian-upper Tortonian. Cilento Basin that at that time was adjacent to the Calabria crystalline terrane. 
- The younger-on-older tectonic contacts associated to low-angle normal faults present onshore of the SCM can be associated to Messinian forerarc extension.

- During the Pliocene this sector, lying at the margin of the Tyrrhenian basin, was affected by uplift coeval to the thrust belt translation on the Apulia Platform.

- Three rifting stages (not homogeneously distributed) affected the region since the Lower Pleistocene. They are associated to the deposition of a thick Quaternary succession (A, B and C units). During these Pleistocene stages there was an abrupt change of the extension direction (from NE-SW to NW-SE) associated to a change of the nappe transport direction of the Southern Apennines.

- Regional sections the Southern Apennines and the results of this paper show that Quaternary normal faults, linked to the late stage of the Tyrrhenian rifting, offset the thrust belt.

- The estimated extension values of the SCM range between 0.18 and 0.12 and are comparable to those calculated for other sectors of the Tyrrhenian margin and other extensional regions worldwide.

Acknowledgments. We thank the Guest editor of this OGST issue, Dr. Fadi Henri Nader, for inviting us to prepare this contribution as well as for his thorough editorial work on the manuscript. We acknowledge the useful review done by two anonymous referees. This study was funded by Università del Sannio (FRA 2017). We acknowledge IHS Inc. which provided the Kingdom software.

\section{References}

Amato A., Ascione A., Cinque A., Lama A. (1991) Morfoevoluzione, sedimentazione e tettonica recente dell'alta Piana del Sele e delle sue valli tributarie (Campania), Geogr. Fis. Din. Quat. 14, 5-16.

Amicucci L., Barchi M.R., Montone P., Rubiliani N. (2008) The Vallo di Diano and Auletta extensional basins in the southern Apennines (Italy): a simple model for a complex setting, Terra Nova 20, 475-482.

Bigi S., Conti A., Casero P., Ruggiero L., Recanati R., Lipparini L. (2013) Geological model of the central Periadriatic basin (Apennines, Italy), Mar. Pet. Geol. 42, 107-121.

Bonardi G., Amore F.O., Ciampo G., De Capoa P., Miconnet P., Perrone V. (1988) Il complesso liguride Auct.: stato delle conoscenze e problemi aperti sulla sua evoluzione preappenninica ed i suoi rapporti con l'Arco calabro, Mem. Soc. Geol. Ital. 41, 17-36.

Cammarosano A., Cavuoto G., Danna M., De Capoa P., De Rienzo F., Di Stasio A., Giardino S., Martelli L., Nardi G., Sgrosso A., Toccacelli R.M., Valente A. (2004) Nuovi dati sui flysch del Cilento (Appennino meridionale, Italia), Boll. Soc. Geol. Ital. 123, 253-273.

Casciello E., Cesarano M., Conforti A., D'Argenio B., Marsella E., Pappone G., Sacchi M. (2004) Extensional Detachment Geometries on the Tyrrhenian Margin (the Salerno District), in: Pasquarè G., Venturini C., Groppelli G. (eds), Mapping geology in Italy, APAT, Roma, pp. 29-34.
Catalano S., Monaco C., Tortorici L. (2004) Neogene-Quaternary tectonic evolution of the southern Apennines, Tectonics 23, TC2003, https://doi.org/10.1029/2003TC001512.

Channell J.E.T., Rio D., Sprovieri R.Glacon R. (1990) Biomagnetostratigraphic correlations from Leg 107 in the Tyrrhenian Sea, in: Kastens K.A., Mascle J., Cita M.B., McCoy F. (eds), Proc. ODP, Sci. Results 10\%, Ocean Drilling Program, College Station, TX, pp. 669-682.

Cinque A., Guida F., Russo F., Santangelo N. (1988) Dati cronologici e stratigrafici su alcuni depositi continentali della Piana del Sele (Campania): i "Conglomerati di Eboli", Geogr. Fis. Din. Quat. 11, 39-44.

Critelli S., Le Pera E. (1994) Detrital modes and provenance of Miocene sandstones and modern sands of the southern Apennines thrust-top basins (Italy), J. Sediment. Res. A64, 824-835.

De Donatis M. (2001) Three-dimensional visualization of the Neogene structures of an external sector of the northern Apennines, Italy, Am. Assoc. Pet. Geol. Bull. 85, 419-431.

De Rita D., Giordano G. (1996) Volcanological and structural evolution of Roccamonfina volcano (Italy): origin of the summit caldera, Geol. Soc. Spec. Publ. 110, 209-224.

Dhont D., Luxey P., Chorowicz J. (2005) 3-D modeling of geologic maps from surface data, Am. Assoc. Pet. Geol. Bull. 89, 1465-1474.

Dix C.H. (1955) Seismic velocities from surface measurements, Geophysics 20, 68-86.

Ferraro L., Pescatore T.S., Russo B., Senatore M.R. (1997) Studi di geologia marina sul margine tirrenico: la piattaforma continentale tra Punta Licosa e Capo Palinuro (Tirreno meridionale), Boll. Soc. Geol. Ital. 116, 473-485.

Gars G., Lippman M. (1984) Nouvelle donnees neotectonique dans l'Apennin campanien (Italie du Sud), Comptes Rendus Acad. Sci. Paris 298, II-11, 495-500.

Gibbs A.D. (1983) Balanced section constructions from seismic sections in areas of extensional tectonics, J. Struc. Geol. 5, 153-160.

Knott S.D. (1987) The Liguride Complex of southern Italy - a Cretaceous to Paleogene accretionary wedge, Tectonophysics 142, 217-226.

Knott S.D., Turco E. (1991) Late Cenozoic kinematics of the Calabrian Arc, southern Italy, Tectonics 10, 1164-1172.

Malusà M.G., Danišík M., Kuhlemann J. (2016) Tracking the Adriatic-slab travel beneath the Tethyan margin of Corsica-Sardinia by low-temperature thermochronometry, Gondwana Res. 31, 135-149, https://doi.org/10.1016/ j.gr.2014.12.011.

Marani M.P., Gamberi F., Bortoluzzi G., Carrara G., Ligi M., Penitenti D. (2004) Seafloor morphology of the Tyrrhenian Sea, in: Marani M.P., Gamberi F., Bonatti E. (eds), From seafloor to deep mantle: architecture of the Tyrrhenian Backarc Basin, Memorie Descrittive della Carta Geologica d'Italia, vol. 44, APAT, Roma, pp. 1-194.

Massari F., Prosser G. (2013) Late Cenozoic tectono-stratigraphic sequences of the Crotone Basin: insights on the geodynamic history of the Calabrian arc and Tyrrhenian Sea, Basin Res. 25, 26-51, https://doi.org/10.1111/j.13652117.2012.00549.x.

Mattei M., Cifelli F., D'Agostino N. (2007) The evolution of the Calabrian Arc: evidence from paleomagnetic and GPS observations, Earth Planet. Sci. Lett. 263, 259-274, https://doi.org/10.1016/j.epsl.2007.08.034. 
Mazzoli S., D'Errico M., Aldega L., Corrado S., Invernizzi C., Shiner P., Zattin M. (2008) Tectonic burial and "young", $(<10 \mathrm{Ma})$ exhumation in the southern Apennines fold-andthrust belt (Italy), Geology 36, 243-246, https://doi.org/ 10.1130/G24344A.1.

Mellere D., Zecchin M., Perale C. (2005) Stratigraphy and sedimentology of fault-controlled backstepping shorefaces, middle Pliocene of Crotone Basin, Southern Italy, Sediment. Geol. 176, 281-303.

Menardi-Noguera A., Rea G. (2000) Deep structure of the Campanian-Lucanian Arc (Southern Apennines, Italy), Tectonophysics 324, 239-265.

Miconnet P. (1988) Evolution mesozoique du secteur de Lagonegro, Mem. Soc. Geol. Ital. 41, 321-330.

Milia A., Torrente M.M. (1997) Evoluzione tettonica della Penisola Sorrentina (Margine Pertirrenico Campano), Boll. Soc. Geol. Ital. 116, 487-502.

Milia A., Torrente M.M. (1999) Tectonics and stratigraphic architecture of a pery-Tyrrhenian half-graben (Bay of Naples, Italy), Tectonophysics 315, 297-314.

Milia A., Torrente M.M. (2011) The possible role of extensional faults in localizing magmatic activity: a crustal model for the Campanian volcanic zone (eastern Tyrrhenian Sea, Italy), $J$. Geol. Soc. 68, 471-484.

Milia A., Torrente M.M. (2014) Early-stage rifting of the Southern Tyrrhenian region: the Calabria-Sardinia breakup, J. Geodyn. 81, 17-29, https://doi.org/10.1016/j.jog.2014. 06.001.

Milia A., Torrente M.M. (2015a) Tectono-stratigraphic signature of a rapid multistage subsiding rift basin in the Tyrrhenian-Apennine hinge zone (Italy): A possible interaction of upper plate with subducting slab, J. Geodyn. 86, 4260, https://doi.org/10.1016/j.jog.2015.02.005.

Milia A., Torrente M.M. (2015b) Rift and supradetachment basins during extension: insight from the Tyrrhenian rift, $J$. Geol. Soc. 72, 5-8, https://doi.org/10.1144/jgs2014-046.

Milia A., Torrente M.M., Russo M., Zuppetta A. (2003) Tectonics and crustal structure of the Campania continental margin: relationships with volcanism, Mineral. Petrol. 79, 33-47.

Milia A., Turco E., Pierantoni P.P., Schettino A. (2009) Fourdimensional tectonostratigraphic evolution of the southeastern peri-Tyrrhenian Basins (Margin of Calabria, Italy), Tectonophysics 476, 41-56.

Milia A., Torrente M.M., Massa B., Iannace P. (2013) Progressive changes in rifting directions in the Campania margin (Italy): new constrains for the Tyrrhenian Sea opening, Glob. Planet. Change 109, 3-17, https://doi.org/10.1016/ j.gloplacha.2013.07.003.

Milia A., Valente A., Cavuoto G., Torrente M.M. (2017d) Miocene progressive forearc extension in the Central Mediterranean, Tectonophysics 710-711, 232-248, https://doi.org/ 10.1016/j.tecto.2016.10.002.

Milia A., Torrente M.M., Tesauro M. (2017c) From stretching to mantle exhumation in a triangular backarc basin (Vavilov basin, Tyrrhenian Sea, western Mediterranean), Tectonophysics 710-711, 108-126, https://doi.org/10.1016/ j.tecto.2016.10.017.

Milia A., Iannace P., Tesauro M., Torrente M.M. (2017a) Upper plate deformation as marker for the Northern STEP fault of the Ionian slab (Tyrrhenian Sea, central Mediterranean), Tectonophysics 710-711, 127-148, https://doi.org/10.1016/ j.tecto.2016.08.017.
Milia A., Torrente M.M., Iannace P. (2017b) Pliocene-Quaternary orogenic systems in Central Mediterranean: the ApuliaSouthern Apennines-Tyrrhenian Sea example, Tectonics 36, 1614-1632, https://doi.org/10.1002/2017TC004571.

Milia A., Iannace P., Tesauro M., Torrente M.M. (in press) Marsili and Cefalù basins: the evolution of a rift system in the southern Tyrrhenian Sea (Central Mediterranean), Glob. Planet. Change 1, 1-2, https://doi.org/10.1016/j.gloplacha. 2017.12.003.

Mitchum R.M., Vail P.R., Sangree J.B. (1977) Seismic stratigraphy and global changes of sea level. Part 6: stratigraphic interpretation of seismic reflection patterns in depositional sequences, in: Payton C.E. (ed.), Seismic Stratigraphy Application to Hydrocarbon Exploration, American Association of Petroleum Geologists Memoir, vol. 26, Tulsa, Oklahoma, pp. 117-133.

Monaco C., Tortorici L., Catalano S., Paltrinieri W., Steel N. (2001) The role of Pleistocene strike-slip tectonics in the Neogene-Quaternaryevolution of the southern Apennine orogenic belt: implications for oil trap development, J. Pet. Geol. 24, 339-359.

Monaco C., Tortorici L., Paltrinieri W. (1998) Structural evolution of the Lucanian Apennines, southern Italy, J. Struc. Geol. 20, 617-638.

Mostardini F., Merlini S. (1986) Appennino Centro Meridionale, sezioni geologiche e proposta di modello strutturale, $\mathrm{Mem}$. Soc. Geol. Ital. 35, 177-202.

Nunns A.G. (1991) Structural restoration of seismic and geologic sections in extensional regimes, Am. Assoc. Pet. Geol. Bull. 75, 278-297.

Oldow J.S., D'Argenio B., Ferranti L., Pappone G., Marsella E., Sacchi M. (1993) Large-scale longitudinal extension in the Southern Apennines contractional belt, Italy, Geology 21, 1123-1126.

Patacca E., Scandone P. (2001) Late thrust propagation and sedimentary response in the thrust belt-foredeep system of the Southern Apennines (Pliocene-Pleistocene), in: Vai G.B., Martini I.P. (eds), Anatomy of a mountain belt: the Apennines and adjacent Mediterranean Basins, Kluwer Academic Publishers, Dordrecht, pp. 401-440.

Patacca E., Sartori R., Scandone P. (1990) Tyrrhenian basin and Apenninic arcs: kinematic relations since late Tortonian times, Mem. Soc. Geol. Ital. 45, 425-451.

Pepe F., Bertotti G., Cella F., Marsella E. (2000) Rifted margin formation in the south Tyrrhenian Sea: a high-resolution seismic profile across the north Sicily passive continental margin, Tectonics 19, 241-257.

Rouby D., Rouby Fossen.H., Cobbold P.R. (1996) Extension, displacement, and block rotation in the larger Gullfaks area, northern North Sea: determined from map view restoration, AAPG Bull. 80, 6, 875-890.

Roure F., Casero P., Addoum B. (2012) Alpine inversion of the North African margin and delamination of its continental lithosphere, Tectonics 31, TC3006, https://doi.org/10.1029/ 2011TC002989.

Rowan M.G., Kligfield R. (1989) Cross section restoration and balancing as an aid to seismic interpretation in extensional terranes, AAPG Bull. 73, 955-966.

Sacchi M., Infuso S., Marsella E. (1994) Late-Pliocene-Early Pleistocene compressional tectonics in offshore Campania (Eastern Tyrrhenian Sea), Boll. Geofis. Teor. Appl. 36, 141/144, 469-482. 
Sartori R. (1990) The main results of ODP Leg 107 in the frame of neogene to recent geology of Perityrrhenian areas, in: Kastens K.A., Mascle J., Cita M.B., McCoy F. (eds), Proc. ODP, Sci. Results 10\%, Ocean Drilling Program, College Station, TX, pp. 715-730.

Sartori R. (2003) The Tyrrhenian back-arc basin and subduction of the Ionian lithosphere, Episodes 26, 3, 217-221.

Scandone P. (1967) Studi sulla geologia lucana: La serie calcareo-silico-marnosa e i suoi rapporti con l'Appennino calcareo, Boll. Soc. Natur. Napoli 76, 1-175.

Schiattarella M. (1996) Tettonica della catena del Pollino (Confine Calabro-Lucano), Mem. Soc. Geol. Ital. 51, 543-566.

Schiattarella M., Beneduce P., Di Leo P., Giano S.I., Giannandrea P., Principe P. (2005) Assetto strutturale ed evoluzione morfotettonica quaternaria del vulcano del Monte Vulture (Appennino lucano), Boll. Soc. Geol. Ital. 124, 543-562.

Schiattarella M., DiLeo P., Beneduce P., Giano S.I., Martino C. (2006) Tectonically driven exhumation of a young orogen: an example from the southern Apennines, Italy, in: Willet S.D., Willet S.D., Hovius N., Brandon M.T., Fisher D.M. (eds), Tectonics, climate and landscape evolution, Penrose Conference Series, vol. 398, Geological Society of America Special Paper, Boulder, pp. 371-385.

Smith J.F. (ed) (2005) Digital geoscience spatial model project final report, Brit. Geol. Sur. Occas. Publ. 9, 56.

Suc J.P., Combourieu-Nebout N., Seret G., Popescu S.P., Klotz S., Gautier F., Clauzon G., Westgate J., Insinga D., Sandhuj
A.S. (2010) The Crotone series: a synthesis and new data, Quat. Inter. 219, 121-133.

Torrente M.M., Milia A. (2013) Volcanism and faulting of the Campania margin (Eastern Tyrrhenian Sea, Italy): a threedimensional visualization of a new volcanic field off Campi Flegrei, Bull. Volcanol. 75, 6, 1-13, https://doi.org/10.1007/ s00445-013-0719-0.

Turco E., Schettino A., Macchiavelli C., Pierantoni P.P. (2013) A plate kinematics approach to the tectonic analysis of the Tyrrhenian-Apennines system, Rend. Online Soc. Geol. Ital. 29, 187-190.

van Hinsbergen D.J.J., Wissers R.L.M., Spakman W. (2014) Origin and consequences of western Mediterranean subduction, rollback and slab segmentation, Tectonics 33, 393-419, https://doi.org/10.1002/2013TC003349.

ViDEPI (2009) Progetto Visibilità Dati Esplorazione Petrolifera in Italia, 2009-2010, Ministero dello Sviluppo Economico, UNMIG, Società Geologica Italiana, Assomineraria, http:// unmig.sviluppoeconomico.gov.it/videpi/.

Vitale S., Ciarcia S. (2013) Tectono-stratigraphic and kinematic evolution of the southern Apennines/Calabria-Peloritani Terrane system (Italy), Tectonophysics 583, 164-182, https://doi.org/10.1016/j.tecto.2012.11.004.

Zecchin M. (2005) Relationships between fault-controlled subsidence and preservation of shallow-marine small-scale cycles: example from the lower Pliocene of the Crotone Basin (southern Italy), J. Sediment. Res. 75, 300-312. 